October 2013

"Trade, Self-Governance,and the Provision of Law and Order, with an Application To Medieval English Chartered Towns"

Charles Angelucci and Simone Meraglia 


\title{
TRADE, SELF-GOVERNANCE, AND THE PROVISION OF LAW AND ORDER, WITH AN APPLICATION TO MEDIEVAL ENGLISH CHARTERED TOWNS*
}

\author{
Charles Angeluccił Simone Meraglia
}

October 23, 2013

\begin{abstract}
We build a model to investigate the interaction between trade, the supply of law and order, and the nature of governing political institutions. To supply law and order necessary for a representative merchant to create wealth, a ruler (i) appoints officials capable of coercion and (ii) introduces a system of taxation. When potential gains from trade are important, the demand for law and order is high but appointing numerous officials capable of coercion may pave the way to arbitrary and distortive expropriation. Delegating the task of appointing officials to the better-informed merchant lowers the cost of sustaining good market institutions, but exacerbates the latter's temptation to escape taxation. When gains from trade are instead low delegation never occurs. Our theory provides a rationale for the case of post-Norman Conquest England (1066-1307) where, in parallel with the rise of trade, kings increasingly give in to the citizens' desire of self-governance by granting Charters of Liberties.
\end{abstract}

Keywords: Institutions, Law Enforcement, Trade, Delegation, Taxation, Bureaucracy.

JEL Classification Numbers: D02, D23, D73, P14, P16.

*We are particularly indebted to Alberto Bisin, Roberta Dessí, Patrick Rey, Andrei Shleifer, Ennio Stacchetti and Jean Tirole for useful comments and suggestions. We also thank Daron Acemoglu, James Anderson, Nava Ashraf, Julia Cagé, Joyee Deb, Mark Dincecco, Georgy Egorov, Jeffry Frieden, Avner Greif, Oliver Hart, Bruno Jullien, Alessandro Lizzeri, Nicola Persico, Shanker Satyanath, David Stasavage, seminar participants at Harvard, MIT, NYU, Boston College, Tsinghua University, University of Bologna, and all the participants to the 2012 IIO Conference in Washington D.C. and the 2013 EARIE Conference in Evora for useful discussions. All the remaining errors are ours.

${ }^{\dagger}$ Department of Economics, Harvard University. E-mail: cangelucci@fas.harvard.edu.

$\ddagger$ Toulouse School of Economics and Department of Economics, University of Bologna. simone.meraglia@tse-fr.eu. 
Sheriffs and reeves, whose office was justice and judgment, were more terrible than thieves and plunderers, and more savage than the most savage.

Henry of Huntingdon (c. 1088 - c. 1154), in Bisson [2008], p. 178.

\section{Introduction}

Much work has been devoted to the causes and consequences of political institutions (see North and Thomas [1973], Greif et al. [1994], and Acemoglu and Robinson [2000, 2001]). It emerges that the power-holders' inability to commit not to expropriate citizens is central to understanding institutional dynamics, and that political institutions - here to be interpreted as enfranchisement of the citizenry - often serve the purpose of making expropriation less tempting. A natural question that also arises when studying institutional choices is that of the provision of market supporting institutions, in particular law and order such as courts and the police (Dixit [2003], Besley and Persson [2009]), and increasing attention has being paid to the interaction between both kinds of institutions (Greif [2005], Acemoglu and Robinson [2006], North et al. [2009]). ${ }^{1}$

We contribute to this literature by providing a novel and formal theory based on three observations. First, the demand for law and order is high when trade is important. Second, for this demand to be met, there must exist a bureaucracy capable of coercion. Third, a bureaucracy capable of coercion is also capable of expropriation. We build a model that shows how the issue of controlling law enforcers is relevant to the design of political institutions and, in turn, to the design of market institutions necessary for society to create wealth. ${ }^{2}$

\footnotetext{
${ }^{1}$ See also Cervellati et al. [2008] on the interaction between institutions designed to protect the citizenry against expropriation by the ruler on the one hand, and the protection of property rights amongst citizens on the other.

${ }^{2}$ We borrow the definition of society from North, Wallis and Weingast [2009] (pag. 14): "the aggregate of individuals collectively dealing with a range of individual decisions in such a way to produce common and shared beliefs about choices, consequences, and outcomes."
} 
Our motivating example is post-Norman Conquest England (1066-1307). This period marks the beginning of a transition from an almost purely manorial economy to one increasingly relying on trade (Usher [1920], Pirenne [1925], Lopez [1971]). ${ }^{3} 4$ Several explanations for the rise of trade may be invoked, as for instance population growth (North and Thomas [1973], Ryerson [1999]), regained access to Mediterranean trade (Pirenne [1925]) and, in England, a feudal but stable society following the Norman Conquest (Tait [1936], pag. 136). This transition goes hand in hand with the appointment by the king of local officials in charge of both providing law and order and collecting taxes (Ballard [1913], Green [1986]). ${ }^{5}$

Evidence available to us is strongly indicative of discretionary and disruptive behavior by these local officials (Ballard [1904], Bisson [2008]). ${ }^{7}$ Not surprisingly, complaints are lodged by citizens and the king has little choice but to intervene (Bisson [2008]). At least two major country-wide investigations are launched to verify allegations of misbehavior (in 1169 and in 1274-1275), new officials are appointed whose main function is to audit local officials, and explicit references to this problem are frequently encountered in statutes and charters (including the Magna Charta).

\footnotetext{
${ }^{3}$ This period is sometimes referred to by Historians as the "Revival of Trade" or the "Commerce Revolution" (see Lopez [1971]).

${ }^{4}$ By a manorial economy we intend a system in which the produce of each manor (say a piece of land) is not traded. See Usher [1920] pag. 131. Also, see Maitland [1897] for the description of a manorial economy as a type of rural economy.

${ }^{5}$ Scholars refer to the body of customs regulating trade among merchants during Medieval times as the lex mercatoria. It has been debated whether this law requires some intervention by the local seigneurial courts to be sustainable. Evidence strongly supports reliance on the local bureaucracy (Kadens [2004], Sachs [2006]).

${ }^{6}$ Courts are easily turned into extortion machineries. This affects the efficiency of the judicial system as, for instance, suitors are reluctant to attend them. See Stubbs [1905] pag 342-343 and pag. 450, and Ballard [1913] pag. lxii. Such misbehavior tends to be attributed to the practice of tax farming whereby local officials are asked to make periodic fix payments to the king that reflect their boroughs' revenues: this gives the former strong incentives to over-extract coercively and pocket the difference (Stubbs [1905], pag. 466-467). See Kiser [1994] for an informal discussion of the incentives faced by a tax farmer when collecting surcharges from the tax base.

${ }^{7}$ The presence of centralized markets, needed for trade to occur, gives rise to opportunities for extortions. In addition, merchandize must pass through checkpoints (ports, bridges, etc.) guarded by the ruler's men. Finally, commercial agreements, to be enforced, are notified to authorities.
} 
By the middle of the twelfth century a new pattern in the English institutional landscape emerges: upon payment of an amount of money, the king increasingly relies on townsmen directly to act as farmers for the revenues they generated. ${ }^{8}$ Through obtaining Charters of Liberties towns are granted by the king the right to appoint and fire officials in charge of local administration (including that of justice) and tax collection. As we document, this phenomenon is large in scale: 53 out of circa 145 boroughs under direct royal control are endowed with these liberties by the end of the period of interest, and these include almost all major towns. Charters institute self-governance at the local level and are arguably among the first forms of political institutions since the Dark Ages. ${ }^{9}$

Our interpretation of these events relies on efficiency considerations mostly: we make the case that charters allowed for better market institutions because of the informational advantage towns enjoyed concerning the local officials' actions. ${ }^{10} 11$ Consistently with this rationale, data show a remarkable difference between royal and mesne towns, i.e. towns that are under the immediate lordship of a local power-holder rather than the king. Local lords, arguably better able to monitor their officials, appear to be sig-

\footnotetext{
${ }^{8}$ See Stubbs [1905], pag. 482. Payment for the grant of liberties may involve either an up-front payment and/or an increment of the yearly sum to be paid back to the king. In 1131, London pays one-hundred marks to obtain the right to appoint sheriffs in charge of judicial and fiscal matters. The citizens of Lincoln are granted the right to "hold their city in chief of the king" in exchange of twohundred marks of silver and four of golds (Stubbs [1905], pp. 164). Similarly, the city of Cambridge pays "three-hundred marks of silver, and one mark of gold, to have their town at ferm, and be exempt from the intermeddling of the sheriff" (Stubbs [1905], pp. 165).

${ }^{9}$ Political power in towns is concentrated among the wealthiest citizens (see Maitland [1897], pag. 212). Arguably, this occurs because wealthy citizens contribute the most to the farm of the town. This is of little concern to us as we are interested in investigating the delegation of authority from coercive power-holders to wealth-creators, be them wealthy or not.

${ }^{10}$ The theory we put forward in this paper does not assume that towns are better able to control officers for physical reasons - one could find arguments going either way - but simply that towns are better informed about the behavior of officials than the king. This, in turn, and as we microfound in the Technical Appendix, allows towns to engage in relational contracts with officials that exhibit more favorable terms.

${ }^{11}$ Civic councils, acting as both the legislature and judicature, enforce the urban law through special courts and by employing lower officials receiving a salary (Volckart and Mangels [1999] and the references therein).
} 
nificantly less prone to delegating control of the bureaucracy to the citizenry. ${ }^{12} 13$ Two towns - Liverpool in 1266 and Newcastle-under-Lyme toward the end of the thirteenth century - lose the liberties previously granted them by the king when becoming under a local lord's control (Ballard and Tait [1923], pag. lvi).

In order to capture these events, we build a model in which a ruler chooses the number of local officials to appoint, where officials possibly perform two tasks: (i) supply law and order (market institutions) for a representative merchant to use and produce wealth, and (ii) collect taxes. ${ }^{14}$ Law and order, by fostering trade, allows for gains from specialization. Appointment rights may be delegated to the merchant. The wealth created is here endogenous to the provision of market institutions and the associated scope for expropriation: the larger the number of employed officials, the higher the wealth potentially created and expropriated. Expropriation, physically carried by the officials, may or may not be induced by the ruler. The interaction being repeated, a self-sustainable Social Contract - an understanding between the ruler and the merchant over taxation and the quality of market institutions - may be reached. The degree of achieved economic efficiency depends on both the officials' ability to appropriate wealth and the merchant's ability to escape taxation. ${ }^{15}$ In such a framework we investigate how the allocation of the right to appoint officials affects the terms of the social contract, and in particular the quality of market institutions.

Key to our analysis is the multitasking problem at the officials' level, as well as

\footnotetext{
${ }^{12}$ Only 11 grants are documented among circa 120 mesne towns (see Section 5) In addition, one could argue that "delegating" control over a territory to a local lord is itself a form of self-governance. While we do not necessarily disagree with this view, we are instead interested in the instances in which the delegation of rights over taxation and administration concerns the creators of wealth directly.

${ }^{13} \mathrm{We}$ employ the term bureaucracy even though we are aware of the fact that a routine-based bureaucracy (intended in modern terms) may hardly have been in place in the course of the eleventh and twelfth century. However, from the reign of Henry II onward, kings attempt to establish a formal bureaucratic body (e.g. the Exchequer).

${ }^{14}$ For simplicity we model officials in a reduced form during most of the analysis. This is relaxed in a Technical Appendix.

${ }^{15}$ See Buchanan [1975] for an analysis of the Social Contract in the absence of a third party enforcer.
} 
the different ability for the ruler and the citizenry to monitor misbehavior. The ruler being only imperfectly able to monitor officials, a rent needs to be given up to prevent arbitrary expropriation. When the efficient size of the bureaucracy needed to sustain trade makes expropriation tempting, a rent-efficiency trade-off arises. The closer the size of the bureaucracy to the efficient level, the higher the total rent that the ruler must give up to avoid arbitrary and unobservable expropriation by officials. ${ }^{16}$

The merchant represents a natural way out from this trade-off: it may be profitable to grant him appointment rights since he is naturally better informed about the exactions he suffers, and thus able to pay a lower rent to the officials. The practice consisting of setting towns at farm to their burgesses comes into existence: the merchant is in charge of collecting the tax to be transferred to the ruler, and enforces the law. This however implies a loss of control to the ruler over the bureaucracy and, therefore, a higher temptation for the merchant to escape taxation.

Only when trade calls for a high demand for law enforcement does the rent-efficiency trade-off arise and is delegation appealing to the ruler. If the officials' sole task was to collect the tax instead - i.e. the demand for law enforcement is low - enfranchisement of (grant of political institutions to) the merchant would never take place.

Our analysis also points to the importance of considering a repeated interaction between the ruler and the merchant: by allowing the creation of a peaceful system of taxation, that is one different from coercive appropriation of wealth, the repeated interaction creates room for officials' expropriation in the first place and, by way of consequence, political institutions.

\footnotetext{
${ }^{16}$ In the Technical Appendix, the ruler chooses the size of the bureaucracy in a town, as well as the optimal relational contract between herself and the officials who both enforce the law and collect taxes. Very much like tax farming, a relational contract consists of a self-sustaining (by the threat of firing) stream of transfers to be made by the local bureaucracy to the ruler contingent on the realized level of trade (say the number of merchants visiting the market). In this setting, any appropriation of wealth by officials higher than the agreed upon level of taxation (between the ruler and the citizenry) reduces potential trade in subsequent periods.
} 
To sum up, this paper sheds light on the relationship between trade, political institutions, and market institutions. An increase in the importance of trade goes hand in hand with a stronger bureaucracy capable of enforcing law and order. A strong bureaucracy is however potentially highly disruptive and preventing expropriation is costly. Enfranchising the citizenry allows for a higher investment in market institutions by lowering the cost of keeping a strong bureaucracy benevolent.

Concerning the course of events we seek to explain, it is undeniable that wars and more generally the need to raise extra revenues also played an important role in several occasions in fostering the grant of liberties by Medieval English rulers. In our view, however, the fact that the delegation of appointment rights would be bargained over constitutes further evidence of how much of an issue the misbehavior by local officials was.

Also, the emergence and spread of self-governance among towns occurs in other parts of Western Europe such as France and Northern Italy. In these areas, self-governing towns are organized as communes that are characterized by an element of mutual protection against forced expropriation by territorial overlords. It is documented that, at least for several towns, (the threat of) civil unrest plays a major role in explaining the arrival of this institutional structure (Thierry [1867]), thereby contradicting the efficiency rationale put forward in this paper. ${ }^{17}$ Civil unrest also seems to play a role in England. Two attempts at creating a commune are recorded-namely Gloucester (1169-70) and York (1176) — but are crashed by the king, and Gloucester is punished with the withdrawal of its liberties. ${ }^{18}$ In 1191, London also declares itself a commune and elects a mayor, but sees its prerogatives being withdrawn a few years later. ${ }^{19}$ To

\footnotetext{
${ }^{17}$ The threat of rebellion may be encompassed in our model by means of appropriate strategies.

${ }^{18}$ York obtains the fee-farm (i.e. the perpetual lease of borough's revenues) in 1190 (for six months) and in 1212. See Tait [1936] pag. 176-179.

${ }^{19}$ On the London commune see Tait [1936]. Between 1239 and 1257 only, the liberties of London are suspended on at least ten occasions, and granted again in exchange of a fine (Sheppard [1998] pag. 93). According to Tait [1936], by 1205 four towns have a mayor: London, Winchester, Exeter and
} 
the best of our knowledge, however, there exists no evidence of other episodes of civil unrest that could account for the widespread granting of self-governance observed in England. As Ballard puts it, whilst "many of the French charters were extorted from the lords by riot and revolution, our English charters are always the result of agreement and often of purchase" ${ }^{20}$

Perhaps the most compelling piece of evidence in favor of a voluntary grant of liberties by the king is constituted by the amount of the farm itself: in 1156-57 Lincoln pays 180 sterling for its farm, 40 more than the amount sheriffs accounted for in previous years. In the same vein, townsmen of Andover in 1205 are willing to pay 95 sterling a year, an increase of 15 sterling compared to the farm previously accounted for by the sheriff (Ballard [1913], pag. lxxvi-lxxvii). The same occurs at Gloucester in 1165, where the town is granted at farm and pays an increment of 5 sterling over the yearly farm fixed at 50 sterling (Maitland [1897], pag. 205). Townsmen's higher willingness to pay may well be explained by the lower cost of a more efficient town's administrative capacity.

Related Literature. Our paper puts emphasis on the rise of trade and the specificity of law enforcement as important determinants for the change in the institutional landscape observed in post-Norman Conquest England through the end of the thirteenth century.

Much has been written on the dual role performed by States, and by coercive powerholders in general, when enforcing the law (Lane [1958], Tilly [1985]). ${ }^{21}$ Also much

Lincoln.

${ }^{20}$ Ballard [1913], pag. cix. See also Reynolds [2004].

${ }^{21}$ The dual role played by power-holders when enforcing the law has been recently investigated by Djankow et al. [2003], Besley and Robinson [2010], and Konrad and Skaperdas [2012]. See also Olson [1993] and McGuire and Olson [1996]. Moselle and Polak [2001] build a model in which a predatory State provides protection to peasants. Unlike in our setting, however, the provision of protection does not require any investment in violence by the ruler. 
attention has been devoted to the functioning of political institutions as commitment devices for power-holders (Machiavelli [1994], North and Weingast [1989], Horowitz [1993], Greif, Milgrom and Weingast [1994], Barzel and Kiser [1997], Levi [1999], North [1999], Greif [2005], Myerson [2008]). North and Thomas [1973] highlight the link between the rise of trade and the arrival of more open forms of political institutions. They make the case that as an economy increasingly relies on trade, the scope for political institutions rises because the created wealth is easily appropriable. ${ }^{22}$ Bates and Lien [1985] also highlight the role played by the nature of the available sources of taxation, along with rulers' need to wage wars, in shaping political institutions in fourteenth century England and France. ${ }^{23}$ We depart from these theories in that we place emphasis on the key role played by the bureaucracy needed to provide law and order in shaping the institutional structure.

In this respect, our paper complements (and provides a formalization for) the theory exposed by Gellner [1992]. The relationship between the control of the bureaucracy and the enfranchisement of the citizenry links our paper to the literature on corruption and decentralization of officials' appointment as in Bardhan [2002] and Bardhan and Mookherjee [2006]. The paper is also complementary to De Lara, Greif and Jha [2008], Dessí and Piccolo [2009], and Egorov, Guriev and Sonin [2009]. De Lara, Greif and Jha [2008] point out how administrative power is an important determinant of self-enforcing representative systems. Our paper offers an explanation as to why the ruler may choose to grant administrative power to citizens in the first place. ${ }^{24}$ Dessí and Piccolo [2009] study medieval merchant guilds as a way to forego the rent accruing to privately informed tax collectors. Differently from their framework, our focus is on the rent due to

\footnotetext{
${ }^{22}$ On the ability to appropriate wealth by rulers see also Mayshar, Moav and Neeman [2011].

${ }^{23}$ See also Slivinski and Sussman [2012].

${ }^{24}$ The authors define administrators as encompassing armies, tax farmers, feudal lords, bureaucracies, and self-governed cities. We focus on a professional bureaucracy under the ruler's control. We do not include power feudal lords within this category.
} 
rulers' imperfect ability to monitor tax collectors' predatory behavior. Egorov, Guriev and Sonin [2009] analyze the trade-off rulers face when allowing for free-media. By generating information, free-media lower the rent accruing to the bureaucracy providing a public good. However, free-media also allow citizens to better coordinate and revolt against the ruler. We depart from these theories in that we analyze the link between trade and the specificity of the provision of law and order, which in turn allows us to account for the historical events under consideration.

Sng and Moriguchi [2013] make the case that rulers of larger political units sustain higher costs in monitoring officials in charge of tax collection: this leads to a less efficient provision of public goods. Unlike in their setting, we focus on the dual function performed by officials as a key ingredient in generating such an inefficiency, which may in turn generate a change in the institutional structure.

A vast literature links the granting of political institutions to the need for rulers to raise extra revenues (or increase public debt) so as to finance wars (Bates and Lien [1985], North and Weingast [1989], Stasavage [2011], and Gennaioli and Voth [2012]). While we certainly recognize the importance of this channel of influence, we provide a complementary explanation — one relying solely on economic forces — to account for the rise of political institutions.

Our analysis of market supporting institutions is related to Acemoglu [2005] and Besley and Persson [2009]. In Acemoglu [2005] a consensually strong State may emerge, in which politically weak rulers impose high taxes and generate wealth. We point at the bureaucracy as a main determinant of such an outcome. Besley and Persson [2009] study the determinants of the State's investment in legal and fiscal capacity and show a complementarity between them. We contribute to this line of research by studying how commitment problems affect the design of market and political institutions.

Our paper is also related to the literature on enfranchisement as in Acemoglu and 
Robinson [2000, 2001], and Acemoglu, Ticchi and Vindigni [2010]. In these papers, an elite is in power and, typically, must design institutions so as to either prevent the military or other subgroups of the citizenry from taking over. Lizzeri and Persico [2004] show how the expansion of the franchise can take place even in the absence of the threat of a take-over. Though our paper is close in the spirit to Lizzeri and Persico [2004], we complement these works by investigating the conditions under which the providers of law enforcement (rulers) decide to let go some of their prerogatives in the first place.

Finally, the repeated interaction between a Principal - the ruler or the citizenry and the bureaucracy (presented in the Technical Appendix) borrows from the growing literature on relational incentive contracts as in Levin [2003] and Malcomson [2013].

The paper proceeds as follows: Section 2 introduces the model setting. Section 3 studies the institutional structure in a finitely repeated game. Section 4 solves the infinitely repeated version of the model. Section 5 offers a historical account dedicated to the institutional evolution in post-Norman Conquest England, along with a descriptive analysis of the number and type of liberties granted by rulers. Section 6 concludes. All the proofs are relegated to the Appendix 1. The Technical Appendix in attachment to this paper presents a formal treatment of the repeated relation between a principal (ruler or citizens) and the bureaucracy. ${ }^{25}$

\section{The Model Setting}

We consider the interaction between a ruler $R$, officials $A$, and a representative merchant $M$. For simplicity, we present this model as if it were a game between $R$ and

\footnotetext{
${ }^{25}$ The Technical Appendix is available online at the following link: https://sites.google.com/site/simonemeragliawebpage/research.
} 
$M$ only, treating $A$ in a reduced form instead. ${ }^{26}$ The Technical Appendix solves for the version of the game in which $A$ is a fully-fledged player. The reduced form approach taken here captures the essential economic effect of political institutions.

We now present the players' action spaces and payoffs. Let the Social Contract $S C$ be defined as the pair $\{t, q\}$, where:

- $t \in \mathbb{R}_{+}$represents the (lump sum) tax paid by $M$ to $R$,

- $q \in \mathbb{R}_{+}$represents the size of the bureaucracy, e.g. number of officials.

Ruler: $R$ 's action space is $\Omega_{R}=\left\{I, q_{I}, t_{I}, T_{I}^{R}\right\}$. Subscript $I$ denotes the identity of the player choosing the terms of $S C=\left\{t_{I}, q_{I}\right\}$; terms that can always be rejected by the other player. $R$ chooses $I \in\{R, M\}$, and if $I=M$ we say that political institutions have been granted.

The investment $q$ determines two functions. First, it is an input in the production function $y(q)$ owned by $M$. The higher the number of officials, the greater their ability to enforce contracts and protect trade routes, and thus the higher the potential output. Formally, we take $y(q)$ to be twice continuously differentiable, non-decreasing and concave. ${ }^{27} 28$ Second, it determines $A$ 's ability to coercively appropriate output $y(q)$ through the extraction function $f(q)$. Formally, $f(q)$ is twice continuously differentiable, increasing and concave, with $f(0)=0$. Coercive extraction has a natural

\footnotetext{
${ }^{26}$ This also allows us to analyze a deterministic economy. Uncertainty over the produced output is considered in the Technical Appendix.

${ }^{27}$ The created wealth $y(q)$ depends in general on $M$ 's discount factor: more patient merchants are more able to sustain exchanges even absent a formal system of legal enforcement. To put it differently, a strong system of contract enforcement is needed when merchants are sufficiently short sighted and/or when trade networks expands (see Greif [1993] and Dixit [2003]). We abstract from this effect to ease exposition since our results remain unaffected.

${ }^{28}$ It is possible to build a simple economy in which multiple producers/merchants engage in production and trade. Producers create wealth by exchanging their endowments. The wealth created positively depends on the amount of endowment exchanged (e.g. gains from specialization), which in turn is directly related to both the effectiveness of the legal system and the patience of agents. A formal modeling is available from the authors upon request.
} 
upperbound in the amount of wealth produced $y(q)$. When $I=R, R$ chooses $q$.

$T_{I}^{R}(q) \in[0, \min \{f(q), y(q)\}]$ denotes the wealth $R$ can coercively extract for a given regime of political institutions $I$, wealth produced $y(q)$, and ability to expropriate $f(q)$. In words, $T_{I}^{R}(q) \in[0, \min \{f(q), y(q)\}]$ represents what the ruler can appropriate when ordering officials to engage in expropriation, where $T_{M}^{R}=0$ : when delegating the choice of the Social Contract to $M, R$ loses her ability to coercively extract from $M .^{29} 3031$

To sum up, we have that:

$$
\left\{q_{I}, t_{I}, T_{I}^{R}\right\}=\left\{\begin{array}{cc}
\left\{q_{R}, t_{R}, T_{R}^{R}\right\} & \text { if } I=R, \\
\{\emptyset\} & \text { if } I=M .
\end{array}\right.
$$

$R$ 's payoff is given by:

$$
V_{I}(t, q)=\widetilde{T}_{I}(t, q)-C(t, q)
$$

$C(t, q)$ is the cost of investing in $A$ given its size $q$, which we explain below and microfound in the Technical Appendix. Further, $\widetilde{T}_{I}(t, q) \in[0, \min \{f(q), y(q)\}]$ represents the wealth extracted by $R$ in equilibrium and for a given regime of political institutions $I$ and terms of $S C$. In particular, we have that:

$$
\widetilde{T}_{I}(t, q)=\left\{\begin{array}{cl}
t & \text { if } S C \text { played } \\
T_{I}^{R}(q) & \text { otherwise }
\end{array}\right.
$$

that is $\widetilde{T}_{I}(t, q)$ can either be equal to the tax $t$, or to coercive appropriation (if $I=R$ ).

\footnotetext{
${ }^{29}$ We disregard $R$ 's option to reject the contracted proposed by $M$ when $I=M$. This is with no loss of generality given $T_{M}^{R}=0$.

${ }^{30}$ In the following we skip arguments for the amount $T$ of wealth extracted unless necessary.

${ }^{31}$ In a previous version of this paper we consider the case in which $R$ retains some degree of control over $A$ even though $I=M$. Main results remain unaffected.
} 
Consider now the cost to $R$ of investing in $A$. Formally, we have that:

$$
C(t, q)=\left\{\begin{array}{cl}
c q & \text { if } \widetilde{T} \geq f(q), \\
\underline{c} q^{\diamond}(\widetilde{T})+\bar{c}\left[q-q^{\diamond}(\widetilde{T})\right] & \text { if } \widetilde{T}<f(q), \\
0 & \text { if } I=M,
\end{array}\right.
$$

where $\bar{c}>\underline{c}>0$ and where the quantity $q^{\diamond}(\widetilde{T})$ is explained below. According to (3), when $I=R$, a higher cost of hiring officials arises only if the taxation $R$ requires $A$ to extract from $M$ is lower than the sum $A$ could potentially extract by employing coercion. $^{32}$ The idea here is that, when the number of appointed officials is sufficiently high so as to enable potential coercive over-taxation of $M$ by $A$ (that is, when $\widetilde{T}=t<$ $f(q)), R$ 's inability to observe $A$ 's behavior generates a rent $(\triangle C=\bar{c}-\underline{c})$ necessary to prevent arbitrary expropriation. When instead $R$ induces expropriation by her officials (i.e. $\widetilde{T}=f(q)$ ), a rent no longer needs to be given up since incentives are then aligned. Finally, when $I=M, R$ no longer incurs the cost of investing in $A$.

The specific functional form considered is justified in the Technical Appendix. Define $q^{\diamond}(\widetilde{T})$ as the value of $q$ such that $\widetilde{T}=f(q)$. If the amount extracted $\widetilde{T}$ in (2) is given by $f(q)$, we then have an identity $f(q)=f(q)$, which implies that $q^{\diamond}=q, \forall q \in \mathbb{R}_{+}$. In this case the cost function is given by $C(q)=\underline{c} q$.

Consider now the case in which $\widetilde{T}=t$ in (2), for some fixed $t$. Given the definition for $q^{\diamond}(t)$, and given that $f(q)$ is increasing in $q$, we have that $q<q^{\diamond}(t)$ implies $t>f(q)$, and viceversa. Then, from (4), the cost $\bar{c}$ is incurred only if $q>q^{\diamond}(t)$, i.e. if and only if $t<f(q)$. We then have that:

$$
C(t, q)=\underline{c}\left\{\min \left[q^{\diamond}(t), q\right]\right\}+\bar{c}\left\{\max \left[q-q^{\diamond}(t), 0\right]\right\}
$$

\footnotetext{
${ }^{32}$ The Technical Appendix shows that a higher cost can also arise when $R$ tries to induce her bureaucracy to prey on $M$. We postpone this issue to the analysis of the repeated interaction between $R$ and $M$.
} 
The cost function as defined in (4) has a kink at $q^{\diamond}(t)$. For a given $t$, the marginal cost of investing in $A$ switches from $\underline{c}$ to $\bar{c}>\underline{c}$ at $q=q^{\diamond}(t) .{ }^{33}$

The cost function is assumed independent of $A$ 's discount factor $\left(\beta_{A} \in[0,1)\right)$ and $\underline{u}_{M}$. This is made to ease exposition only. The Technical Appendix derives the cost function for the investment in the local bureaucracy. ${ }^{34}$ It is there formally proven that $C(t, q) \geq \underline{c q}$ for any choice of $q$, with the strict inequality holding when $t<f(q)$, i.e. for $q>q^{\diamond}(t) .{ }^{35}$ All else equal, the more short-sighted $A$ and/or the higher reservation utility for $M$, the higher $\bar{c}$.

Finally, we set $R$ 's reservation utility to zero.

Merchant: $M$ 's action space is given by $\Omega_{M}=\left\{Y(q), q_{I}, t_{I}, a_{I}^{M}\right\}$, where $a_{I}^{M} \in$ $\{0,1\}$ is relevant only when $I=R$ and represents $M$ 's choice as to accept $\left(a_{R}^{M}=1\right)$ or reject $\left(a_{R}^{M}=0\right)$ the transfer $t$ proposed by $R$. Further $Y(q) \in\{0, y(q)\}$ denotes $M$ 's participation decision: $Y=0$ means no participation in the formal economy, and conversely. The other choices have already been described above.

Political institutions amount to enfranchising $M$ by granting him the right to choose q. Formally, political institutions are a way by which $R$ endows $M$ with a technology to replace - and, therefore, appoint $-A$. Political institutions can be thought of as the institution of check and balances over the actual use of force by law enforcers, say popular assemblies and, in medieval times, (merchant) guilds also. Formally, the grant of political institutions causes both a downward shift in the cost of hiring $A$ and a

\footnotetext{
${ }^{33}$ In the course of the analysis, we make sure of $q^{\diamond}$ being well defined when we take into account that $t$ is a function of $q$.

${ }^{34}$ Although in the Technical Appendix we derive the cost function for discrete choices of the size of the bureaucracy, a generalization to a continuum choice is immediate. See the discussion therein.

${ }^{35}$ See Proposition 1 in the Technical Appendix. Clearly, the cost of investing in each officer cannot exceed the sum the officer extracts from the merchants, be it equal to coercive extraction or taxation. If it is so, the cost of investing in the bureaucracy is trivially given by the total sum extracted. Without loss of generality we anticipate this is never a concern, since $R$ always chooses an investment level that allows her to retain some positive profits. Finally, neither is this a concern when $M$ is empowered with decision rights.
} 
transfer of decision rights over the investment in the bureaucracy $(q)$ from $R$ to $M .^{36}$

$M$ 's payoff is given by:

$$
U_{I}(t, q)=\left\{\begin{array}{cc}
y(q)-\widetilde{T}_{R}(t, q) & \text { if } I=R \\
y(q)-\widetilde{T}_{M}(t, q)-\underline{c} q & \text { if } I=M
\end{array}\right.
$$

where $\widetilde{T}_{I}(t, q)$ is given by (2). When $I=M$, the cost investing in $A$ to $M$ is given by $\underline{c} q$. Unlike $R, M$ perfectly observes the wealth he is extracted by the appointed officials. This difference in the monitoring/auditing technology implies that $M$ does not pay a rent to $A$ despite its ability to engage in coercive expropriation. ${ }^{37}$

M's reservation utility is denoted by $\underline{u}_{M} \geq 0$. This may be interpreted as either $M$ 's payoff in the informal economy where output is unobservable to $R$. Another possible interpretation - of clear historical relevance - is that the higher $\underline{u}_{M}$, the more tangible the risk of rebellion.

In the rest of the analysis all subscripts are dropped unless needed.

Timing: The game is infinitely repeated in discrete time $\tau=0,1, \ldots$ Let $\beta_{M}, \beta_{R} \in[0,1)$ represent the players' discount factors. The equilibrium concept is subgame perfection. In every period $\tau$ the timing of the stage game is the following:

1. $R$ chooses $I_{\tau} \in\{R, M\}$;

\footnotetext{
${ }^{36}$ In this paper political institutions are binary: either they are granted or not and, if granted, they amount to $\mathrm{M}$ deciding the investment in the size of the bureaucracy. One may think of a smoother model in which political institutions consist in $R$ deciding how much $M$ can invest in its own bureaucracy, while keeping her own bureaucracy in place. In this case, it may be shown that our main results remain unaffected. See the footnote to the comments following Proposition 2.

${ }^{37}$ Formally, the different ability to monitor officials, makes the merchant able to write a relational incentive contract that results in a lower cost of investing in market institutions when coercion by officials is prevented: the merchant makes a better use of the threat of firing officials when behaving in an extortionary manner. For details, see the Technical Appendix.
} 
2. if $I_{\tau}=M\left(I_{\tau}=R\right), M(R)$ chooses the investment in the bureaucracy $q_{\tau}$;

3. $M$ decides whether to participate $\left(Y_{\tau}\right)$. If $M$ participates, the output $y\left(q_{\tau}\right)$ is produced. Otherwise $Y_{\tau}=0, M$ gets $\underline{u}_{M}, R$ gets zero, and the period ends;

4. if $Y_{\tau}(q)=y\left(q_{\tau}\right), M(R)$ proposes transfer $t_{\tau}$ to $R(M)$. $R(M)$ accepts $a_{\tau}^{R}=1$ $\left(a_{\tau}^{M}=1\right)$ or refuses $a_{\tau}^{R}=0\left(a_{\tau}^{M}=0\right)$. If a rejection occurs (by any player), $R$ extracts $T_{I, \tau}^{R}$.

5. Payoffs materialize.

We wish to emphasize that we assume that the choice of political institutions is not irreversible, i.e. it is made in every period $\tau$. In particular changing political regime is taken to be costless.

Also, throughout our analysis, we seek the equilibrium guaranteeing the highest payoff to whoever is choosing the terms of the social contract. Any different allocation of the bargaining power between the ruler and the merchant does not affect the rationale for the choice of the institutional setting.

Manorial versus Trade economy. In the following sections we divide the analysis by distinguishing between two cases: (i) a manorial economy, i.e. one in which the production of wealth is independent of law enforcement, i.e. $y(q)=\underline{y}=y(0)>\underline{u}_{M}$, and (ii) a trade economy, i.e. one in which wealth production depends on the investment in law enforcement. In case $(i)$ trade plays no role: for instance, the produce of the land is shared between peasants and the lord of the manor who collects part of the produce as taxes via her own bureaucracy (if institutions are not granted). ${ }^{38}$ In case

\footnotetext{
${ }^{38}$ We slightly abuse definition when referring to a manorial economy as one in which trade does not occur. By this terminology we wish to capture an economy concentrated on the hierarchical
} 
(ii), the rise of trade opportunities makes production of wealth more responsive to the provision of law and order. ${ }^{39}$ In this latter case officials perform two functions, namely law enforcement to sustain trade, and tax collection.

Before proceeding, we introduce a technical assumption that ensures a well-behaved problem:

Technical Assumptions: In a trade economy we have:

A1: $\left|\frac{\partial^{2} y(q)}{\partial q^{2}}\right|>\left|\frac{\partial^{2} f(q)}{\partial q^{2}}\right|$.

A1 implies that M's payoff is either decreasing or inversely U-shaped whenever $\widetilde{T}(q)=f(q)$. The technical implications of $\mathbf{A} \mathbf{1}$ are relegated to Appendix 1.

Also, define $q^{*}(\underline{c})$ as the level of $q$ that maximizes surplus $S(q, \underline{c})=[y(q)-\underline{c} q]$ created in the trade economy. We make the following assumption:

A2: In a trade economy, we have $y\left(q^{*}(\underline{c})\right)-f\left(q^{*}(\underline{c})\right)<\underline{u}_{M}$ and $\frac{d f\left(q^{*}\right)}{d q}>\underline{c}$.

In a trade economy, coercive extraction induces $M$ to opt out from the formal economy if the efficient level of market institutions were to be chosen. It is straightforward

relationship between the lord (owner of the manor) and the peasants working the land. The lord collects taxes (perhaps in kind) from the peasantry and consumes the produce of the land without being connected to wide trade networks.

${ }^{39}$ Determinants (different from the provision of law enforcement) of a shift in gains from trade (specialization) may be several, as for instance population growth and occupation of previously uncultivated lands (see North and Thomas [1973]). 
to show that $q^{*}=0$ in a manorial economy: this further implies that in a manorial economy the claim in $\mathbf{A} \mathbf{2}$ does not hold.

Assumptions A1-A2 simply allow us to focus our interest on the two most relevant cases. None of these assumptions affects our results. ${ }^{40}$

We proceed by first presenting the results in the one-period (or finitely repeated) game between $R$ and $M$.

\section{The Ruler-Merchant One-Period Game}

Suppose $R$ and $M$ interact one time only. We solve the one-period game by backward induction. We denote by $S C^{s} \equiv\left\{t^{s}, q^{s}\right\}$ and $I^{s}$ the equilibrium social contract and choice of political institutions, respectively. Consider the case in which $I=R$. Given the level $q$ chosen by $R$ in stage 2 , we necessarily have $t=f(q)$, for $R$ would not find it profitable to request $t<f(q)$ and $M$ would reject any proposal $t>f(q)$. Consequently in the one-period game, absent political institutions $(I=R)$, in the case of a trade economy we have:

$$
\widetilde{T}(q)=\min [f(q), y(q)]
$$

where (6) and (3) imply that $C(q)=\underline{c} q$. Since $A$ cannot extract more than what $R$ demands, no rent $\Delta C$ is incurred. $R$ solves the following problem:

$$
\begin{gathered}
\max _{\{q\}}[f(q)-\underline{c} q] \\
\text { s.t. } \quad y(q)-f(q) \geq \underline{u}_{M},
\end{gathered}
$$

\footnotetext{
${ }^{40} \mathrm{~A}$ formal proof for all the cases that could possible arise is available from the authors upon request.
} 
where (7) ensures M's participation in the formal economy (PC).

In the case of a manorial economy the derivation of $R$ 's program is obvious.

We can now state our first result:

Proposition 1 In the one-period game, taxation is equal to potential extraction and political institutions are not granted independently of whether trade occurs.

In a manorial economy, the ruler over-invests in market institutions. Given A1-A2, in a trade economy an under-investment with respect to the efficient level of law enforcement instead occurs.

Proof. See Appendix 1.

Intuition. Leaving aside the coordination issue between the officials and the ruler for a moment, we have that, on the one hand, a manorial economy induces an inefficient over-investment in the size of the bureaucracy. This comes as a response to the merchant's inability to commit to transfer the ruler a sum greater than what can be coercively extracted were an efficient (namely zero) level of market institutions to be chosen.

In a trade economy, the officials' ability to expropriate the merchants leads to an inefficient under-investment in bureaucracy so as to ensure participation in the formal economy by the merchants. The ruler's (and the officials') lack of commitment is now preventing any movements towards efficiency. Whichever the relevant distortion, it moves the economy afar from efficiency. ${ }^{41}$

\footnotetext{
${ }^{41}$ Acemoglu, Golosov, and Tsyvinski [2008] study a neoclassical growth model in presence of selfinterested politicians able to extract rents. Limiting such behavior causes inefficient labor and capital investment choices. Despite taxation being lump sum, distortions arise. This phenomenon occurs in our model also. Finally, the distinction between a manorial and trade economy is reminiscent of the one between weak and strong States in Acemoglu [2005].
} 
History offers us a stark example of the problem faced by rulers wishing to enlarge their bureaucracy providing law and order. In twelfth-century England, Henry II and his sons experiment a new regime of justice:

Henry had much to change this by 1178 , when a cleric close to the royal court named Roger of Howden summed up his latest exercise of power as follows: "Staying in England, the lord-king questioned the justices he had appointed in England whether they had treated the people of the realm with decent restraint." And when he learned that the people were "overly oppressed" by an excessive "multitude" of justices, the king took "counsel with competent men" and decided to reduce the number of justices from height to five, "namely, two clerics and three laymen, all chosen from his private entourage [familia]" [...]. ${ }^{42}$

The value of this citation is twofold. First, it makes clear that justice and extraction were closely intertwined. Second, it suggests that justices' exactions were conceivably arbitrary rather than voluntarily induced by Henry II. At this point of the analysis, this is of little concern to us: all we are interested in is the link between surplus extraction from the citizenry and investment in law and order. Regardless of officers' behavior being arbitrary or not, an overwhelming ability to extract calls for a reduced investment in law enforcement.

Political institutions are never granted in this one-period setting in which taxation is equal to coercive extraction. This result is intuitive: first, since commitment problems call for coercive extraction at equilibrium, there is no temptation for officers to extract a higher sum. Monitoring of (and/or rent to) the officers is not needed. Second, since taxation is equal to coercive extraction, $R$ does not find it profitable to (possibly) curb her own power to exert coercion over the merchants by granting them

\footnotetext{
${ }^{42}$ Bisson [2008], pp. 378-380.
} 
institutions. Since coercion is employed, any handover of power by $R$ would result in a lower amount of taxes collected.

In the next section, we analyze the infinitely repeated version of this game. Trigger strategies may be employed by $R$ and $M$ in order to sustain $S C$ where taxation differs from coercive extraction, thereby possibly enabling a more efficient investment.

\section{Infinitely Repeated Game}

The infinitely repeated setting is different from the one-period one in that both peaceful taxation and expropriation are feasible, where expropriation is here defined as the extraction by $A$ from $M$ of a sum greater than the one promised in the social contract. When expropriation is an issue, keeping in check $A$ 's behavior is costly to $R$. As formally proven in the Technical Appendix, when gains from specialization are sufficiently high, an efficient level of market institutions $q^{*}(\underline{c})$ implies higher rents for the officials. Also, the rent accruing to each single official grows with the size of $A$ (see Proposition 2 in the Technical Appendix). In the following, in accordance with (3), we do not formally pursue the increase in the cost of investing in each single official brought about by an increment in the size of the bureaucracy. However, this interpretation remains relevant and is discussed below the stated proposition.

In the infinitely repeated setting we first define the history of a game:

$$
h^{\tau}=\left(I^{\tau}, q^{\tau}, Y^{\tau}, t^{\tau}, a_{R}^{\tau}, a_{M}^{\tau},\left(T^{R}\right)^{\tau}\right)
$$

as the collection of sequences of past actions taken by players from period 0 until $\tau-1$.

A subgame perfect equilibrium (SPE) is given by $R$ 's choice of $\widetilde{I}_{\tau}$ given history

$h^{\tau}, \widetilde{q}_{\tau}$ given $\left\{h^{\tau}, I_{\tau}\right\}, M^{\prime}$ 's output production $\widetilde{Y}_{\tau}$ given $\left\{h^{\tau}, I_{\tau}, q_{\tau}\right\}$, a proposal $\widetilde{t}_{\tau}$ given 
$\left\{h^{\tau}, I_{\tau}, q_{\tau}, Y_{\tau}\right\}$, a choice $\widetilde{a}_{I, \tau}$ given $\left\{h^{\tau}, I_{\tau}, q_{\tau}, Y_{\tau}, t_{\tau}\right\}$, and finally $R$ 's extraction choice $T_{I, \tau}^{R}$ as a function of the history $\left\{h^{\tau}, I_{\tau}, q_{\tau}, Y_{\tau}, t_{\tau}, a_{R, \tau}, a_{M, \tau}\right\}$. We focus on the SPE that maximizes $R(M)$ 's payoff when $I=R(I=M)$.

$R$ and $M$ play stationary trigger strategies in which each player threatens to revert to the one-period stage game ever after a deviation from the equilibrium $\widetilde{S C} \equiv\{\widetilde{t}, \widetilde{q}\}$ is detected at any stage in period $\tau$ or in any previous period $\tau^{\prime}=0, \ldots, \tau-1$. More specifically, if the cooperation phase involves the grant of political institutions in addition to a pair $\{\widetilde{t}, \widetilde{q}\}$, the punishment phase implies that $R$ costlessly and forever takes political institutions back should a deviation by any player occur.

Players' deviation from $\widetilde{S C}$ may depend on the grant of political institutions. Absent political institutions, $R$ can deviate at different stages in any single period $\tau:(i)$ at the investment stage, and (ii) at the transfer/expropriation stage. $M$ can also deviate at two stages: $(i)$ at the output production stage and $(i i)$ at the transfer stage (accept/reject a proposal). The temptation to deviate at the transfer stage may occur because of the difference between $\widetilde{t}$ and $f(\widetilde{q})$. If the former is greater than the latter, the temptation to deviate rests on $M$, and viceversa. In presence of political institutions, $R$ cannot deviate at any stage. ${ }^{43}$ If political institutions are granted instead, $R$ cannot deviate at any stage, whilst $M$ can be tempted to deviate either at the investment stage and/or at the transfer one.

Given $\widetilde{I} \in\{R, M\}$ and $\widetilde{S C} \equiv\{\widetilde{t}, \widetilde{q}\}$, we now state the players' Incentive Compatibility Constraints $(\mathbf{I C C}(j))$ for $j=\{R, M\}$. We derive these constraints for the case of a trade economy: the case of a manorial economy is a straightforward variation of the former one.

Consider the case in which $\widetilde{I}=R$. First we analyze $M$ 's incentive to deviate from $\widetilde{S C}$. In any period $\tau, \operatorname{ICC}(M)$ at the transfer stage is given by:

\footnotetext{
${ }^{43}$ Allowing for a deviation by $R$ in period $\tau$ when $I_{\tau}=M$ does not affect our results in any major way.
} 


$$
\frac{y(\widetilde{q})-\widetilde{t}}{1-\beta_{M}} \geq\left[y(\widetilde{q})-T_{R}^{R}(\widetilde{q})\right]+\frac{\beta_{M}}{1-\beta_{M}} U^{s},
$$

where $U^{s}$ is $M$ 's utility in the one-period stage game as defined in Proposition 1. By deviating at the transfer stage, $M$ abides to coercive extraction $T_{R}^{R}(\widetilde{q})=f(\widetilde{q})$ so as to forgo $\widetilde{t}^{44} \mathbf{I C C}(M)$ is rewritten as:

$$
\beta_{M} \geq \frac{\widetilde{t}-f(\widetilde{q})}{[y(\widetilde{q})-f(\widetilde{q})]-U^{s}}
$$

M's temptation to deviate is relevant whenever $\widetilde{t}>f(\widetilde{q})$. Intuitively, since $M$ produces an output $Y_{\tau}(\widetilde{q}) \in\{0, y(\widetilde{q})\}$ according to the level of $\widetilde{T}_{R}(\widetilde{q})$ he expects to pay, a possible deviation at the transfer stage rules out a deviation at the production one, i.e. $M$ optimally chooses to participate in the formal economy.

Let us now analyze $R$ 's incentive to deviate from $\widetilde{S C}$, given $\widetilde{I}=R$. The difference between $\widetilde{t}$ and $T_{R}^{R}(\widetilde{q})$ affects the profitability of deviating at both the investment and the transfer stage. Intuitively, if $\widetilde{t}>T_{R}^{R}(\widetilde{q})$, no deviation is profitable in stage 4 .

If a deviation occurs in stage 2, given the trigger strategy played by $M, R$ replicates the investment in the one-period game. Therefore, by slightly abusing definitions, we name the condition for no-deviations by $R$ in stage 2 as her Participation Constraint $\mathrm{PC}(R)$ :

$$
\frac{\tilde{t}-\underline{c} \widetilde{q}}{1-\beta_{R}} \geq\left[f\left(q^{s}\right)-\underline{c} q^{s}\right]+\frac{\beta_{R}\left[f\left(q^{s}\right)-\underline{c} q^{s}\right]}{1-\beta_{R}}
$$

where $\mathbf{P C}(R)$ is independent of $\beta_{R}$, and where the cost of hiring officers is equal to $\underline{c} .{ }^{45}$ $\mathbf{P C}(R)$ can be rewritten as:

\footnotetext{
${ }^{44}$ Formally, we have $T_{R}^{R}(\widetilde{q})=\min [y(\widetilde{q}), f(\widetilde{q})]$. However, for $M$ to find it tempting to deviate, it must be that $\min [y(\widetilde{q}), f(\widetilde{q})]=f(\widetilde{q})$.

${ }^{45}$ We here anticipate the result in Lemma 1 (see below). A deviation in stage 2 may occur if $\widetilde{t}>f(\widetilde{q})$ only, which further explains why the cost of hiring a single officer is equal to $\underline{c}$ independently of $I_{\tau}$.
} 


$$
\tilde{t}-\underline{c} \tilde{q} \geq f\left(q^{s}\right)-\underline{c} q^{s}
$$

Consider now a deviation in stage 4 , given $\widetilde{I}=R$. Such a deviation is relevant when $\widetilde{t} \leq f(\widetilde{q})$. Therefore, $\mathbf{I C C}(R)$ is given by:

$$
\frac{\widetilde{t}-C(\widetilde{q})}{1-\beta_{R}} \geq\{\min [y(\widetilde{q}), f(\widetilde{q})]-\underline{c} \widetilde{q}\}+\frac{\beta_{R}}{1-\beta_{R}}\left[f\left(q^{s}\right)-\underline{c} q^{s}\right] .
$$

From (4), the first term on the right-hand-side (hereafter RHS) in (10) suggests that, when inducing coercive extraction over $M$, the cost to $R$ of hiring $A$ is given by $\underline{c}^{46}$ After a deviation has occurred, $R$ and $M$ revert to the one-period game ever after, where taxation is equal to coercive extraction. $\mathbf{I C C}(R)$ in $(10)$ can be rewritten as:

$$
\beta_{R} \geq \frac{\{\min [y(\widetilde{q}), f(\widetilde{q})]-\underline{c} \widetilde{q}\}-[\widetilde{t}-C(\widetilde{q})]}{\{\min [y(\widetilde{q}), f(\widetilde{q})]-\underline{c} \widetilde{q}\}-\left[f\left(q^{s}\right)-\underline{c} q^{s}\right]}
$$

We show that either $\mathbf{P C}(R)$ implies $\mathbf{I C C}(R)$, or the reverse holds:

Lemma 1 Provided $\widetilde{I}=R$, when $\widetilde{t}>f(\widetilde{q})$, $R$ 's temptation to deviate occurs at the investment stage only. When $\widetilde{t} \leq f(\widetilde{q})$ instead, $R$ 's temptation to deviate occurs at the extraction stage only.

Proof. See the Appendix.

\footnotetext{
${ }^{46}$ The Technical Appendix provides a formal argument for the cost of inducing predation from $A$ on $M$. Formally, the cost of inducing predation may be higher than $\underline{c}$, and it shrinks as $A$ becomes more short-sighted. Propositions 1 and 2 in the Technical Appendix prove that a sufficiently short-sighted and large bureaucracy make the cost to $R$ of inducing expropriation lower than the cost of preventing it. We expect these conditions to be met when the economy relies on trade.
} 
When $\widetilde{I}_{\tau}=M, \mathbf{I C C}(M)$ is appropriately redefined according to (3) so as to account for the fact that $M$ now incurs the cost of investing in law and order. We have:

$$
\frac{y(\widetilde{q})-\widetilde{t}-\underline{c} \widetilde{q}}{1-\beta_{M}} \geq[y(\widetilde{q})-\underline{c} \widetilde{q}]+\frac{\beta_{M}}{1-\beta_{M}} U^{s}
$$

which is rewritten as:

$$
\beta_{M} \geq \frac{\widetilde{t}}{[y(\widetilde{q})-\underline{c} \widetilde{q}]-U^{s}} .
$$

We anticipate that, since $T_{M}^{R}=0$, a deviation by $M$ at the investment stage is not relevant.

In order to solve for the equilibrium of the game, we proceed by first characterizing $S C_{R}$ that guarantees the highest payoff to $R$ absent political institutions. We then analyze the scope for political institutions along with their impact on the sustainable Social Contract.

\subsection{No Political Institutions}

We here consider $S C_{R}=\left\{t_{R}, q_{R}\right\}$ as the sustainable social contract that maximizes $R$ 's payoff absent political institutions, i.e. $I_{\tau}=R, \forall \tau$. Given that, equilibrium strategies are as described above.

$R$ solves the following problem in each period $\tau$ :

$$
\max _{\{t, q\}}[t-\underline{c} q]
$$

\section{s.t. $\mathbf{B C}, \mathbf{P C}, \mathbf{I C C}(M), \mathbf{P C}(R), \mathbf{I C C}(R)$.}

First note that BC (Budget Constraint) amounts to the objective function being greater or equal than zero, and it is implied by $\mathbf{P C}(R)$. We proceed by dividing the analysis in different cases, depending on the type of economy we consider. 


\subsubsection{Manorial Economy}

In a pure manorial economy the main concern is $M$ 's temptation to renege on $S C_{R}$ at the transfer stage. Movements toward the efficient size of the bureaucracy, i.e. $q^{*}=0$, go hand in hand with an increased temptation to deviate for $M$.

In solving $R$ 's problem, we anticipate that only $\mathbf{I C C}(M)$ binds and control ex-post that all the disregarded constraints hold. In each period $\tau R$ solves:

$$
\max _{\{q\}} \beta_{M}\left\{[\underline{y}-f(q)]-\max \left[\underline{y}-f\left(q^{s}\right) ; \underline{u}_{M}\right]\right\}+f(q)-\underline{c} q
$$

where the cost of hiring officers is equal to $\underline{c}$ since $t_{R} \leq f\left(q_{R}\right)$. The First Order Condition (hereafter FOC) of this problem is given by:

$$
\left(1-\beta_{M}\right) \frac{\partial f(q)}{\partial q}=\underline{c} .
$$

The following Lemma holds:

Lemma 2 The solution lies within the efficient and the "one-period level" of investment and is independent of $R$ 's short-sightedness. The less short-sighted $M$, the closer the economy to efficiency.

Proof. See the Appendix.

A short-sighted merchant impairs movements toward efficiency when law enforcement is not needed. The economy can end up in, or close to, an equilibrium of the finitely repeated game in which coercive extraction is employed by the ruler, with the associated distortion imposed on the economy represented by the cost of the bureaucracy. The ruler tends to over-invest in officials so as to appropriate more of the 
surplus produced by the merchants.

We now turn to the analysis of the trade economy.

\subsubsection{Trade Economy}

In a trade economy law enforcement is an input to output production by $M$. Given A2, $M$ 's deviation is no longer a concern when solving $R$ 's problem. At the efficient level of market institutions $R$ may be tempted to renege on $S C_{R}$. Formally, in each period $\tau R$ solves:

$$
\begin{gathered}
\max _{\{q\}}\left[y(q)-\underline{u}_{M}-C(t, q)\right] \\
\text { s.t. } \operatorname{ICC}(R),
\end{gathered}
$$

where we have substituted for $\mathbf{P C}$ in the objective function.

The following Lemma holds:

Lemma 3 The solution lies within the one-period and the (constrained) efficient level of investment $q^{\circ}(\underline{c}, \bar{c})<q^{*}(\underline{c})$, and it is independent of $M$ 's shortsightedness. All else equal, the less short-sighted $R$, the closer the economy to (constrained) efficiency.

Sufficiently high rents to the officials cause the one-period solution to occur independently of $R$ 's shortsightedness.

Proof. See the Appendix.

In a trade economy approaching an efficient number of officials goes hand in hand with a higher temptation to renege by the ruler. The reason for this temptation is 
twofold. First, the ruler's proceeds from coercive expropriation are higher than the one from taxation. Second, by inducing expropriation, the ruler saves on the (extra-)rent accruing to officials necessary to prevent arbitrary expropriation. If the optimal (to the ruler) level of investment is not sustainable, both sources of temptation force the ruler to distort her investment downward. High levels of short-sightedness and/or high investment costs may even drive the ruler back to the one-period allocation in which she employs coercion to appropriate surplus. This outcome may be interpreted as one involving either a coercion-extraction cycle (Finer [1997]) or the permanent threat of rebellions. In the former case, rulers develop a bureaucracy and finance it by letting officers prey on the merchants. In the latter case, the merchant is allowed to retain its reservation utility only. In both cases the strength of the ruler induces low levels of production.

The rent for officials stems from the fact that they both provide law enforcement and collect taxes (that is, from the fact that they multi-task). This high rent is responsible for the (constrained) optimal investment to fall short of the efficient one. Importantly, such an inefficiency would appear even if the ruler could fully commit to a (peaceful) taxation policy.

As a comparative statics exercise, we explore the role played by $M$ 's reservation utility $\underline{u}_{M}$ on $R$ 's temptation to renege. Intuitively, ceteris paribus, a high investment in the bureaucracy implies that $R$ is increasingly tempted to deviate from $S C_{R}$ as the wealth retained by $M$ goes up. This intuition is further strengthened by the fact that $\underline{u}_{M}$ tends to increase the officials' temptation to expropriate, and hence their rent also (see Proposition 1 in the Technical Appendix). ${ }^{47}$ It is straightforward to show that, were $\underline{u}_{M}$ to be equal to zero, $R$ would be able to select the efficient size of the

\footnotetext{
${ }^{47}$ For a formalization of $\bar{c}$ see section B .2 and Proposition 1 in the Technical Appendix to this paper.
} 
bureaucracy $\left(q^{*}(\underline{c})\right)$ and extract the whole surplus created in the economy.

When $S C_{R}$ fails to move the economy close enough to efficiency, $R$ might consider political institutions as a valuable option.

\subsection{Political Institutions}

Political institutions consist of $R$ delegating to $M$ the monitoring and firing of officials $A$, along with the choice of the investment $q$. Political institutions affect our analysis in two ways: first, they lower the rent accruing to $A$ (i.e. the cost of market institutions) in a trade economy. In this case, delegation of appointment rights to $M$ generates a rent-saving effect measured by $\Delta C$. Second, political institutions determine a shift of bargaining power from $R$ to $M: M$ chooses the terms of $S C_{M}$. By doing so, $M$ bears the cost of investing in market institutions and sets his own taxation so as to leave $R$ indifferent between granting political institutions or not.

We can now state the following result:

Proposition 2 Given $\boldsymbol{A} 2$, all else equal, political institutions are granted if and only if:

(i) there is scope for trade, and

(ii) the merchant is sufficiently patient.

All else equal, political institutions are more likely to occur when the ruler is shortsighted.

When complemented by political institutions, market institutions are at the efficient level $q^{*}(\underline{c})$. 
Proof. See the Appendix.

Intuition. Political institutions are valuable in that they $(i)$ lower the cost of investing in market institutions and (ii) deter (i.e. increase the cost of) potential collusion (communication) between the ruler and the officials. If we were to abstract from $(i i)$, political institutions allow for a more efficient level of market institutions. Control over the bureaucracy is key here.

Political institutions are not granted in a manorial economy since the only function performed by the officials is that of collecting taxes from the merchant. This feature makes control over the officials possible for the ruler through the size of the investment $q$ only. Furthermore, in a manorial economy any movement toward the efficient level of investment in the bureaucracy increases the merchant's temptation to escape taxation. Hence, the ruler cannot gain by granting the right to appoint tax collectors to the merchant who simply cannot commit to any transfer that compensates her.

In a trade economy instead, the ruler may contemplate granting political institutions so as to curb both officials' and her own potential arbitrary behavior, which in turn originates from the fact that officials now performs two tasks. Trade makes a positive level of market institutions desirable. Such a high investment in $q$ however makes expropriation feasible. When a larger bureaucracy is needed to accommodate increasing volumes of trade, the cost of the bureaucracy also increases: each single official fails to internalize the externality imposed by his predatory behavior on other officials (see the Technical Appendix). Keeping officials in check gets more costly to the ruler as officials appropriates a rent. This, in turn, exacerbates the ruler's temptation to induce a coercive behavior in the first place, which further distorts efficiency by requiring lower and lower levels of market institutions.

Delegation of appointment (and firing) rights to the merchant restores efficiency in 
the level of market institutions by lowering their cost. ${ }^{48}$

Finally, all else equal a more short-sighted ruler, say a ruler exerting a war effort, makes the delegation of control rights over the provision of law and order to the merchant more likely. Absent political institutions, her impatience further distorts the investment in the bureaucracy needed to sustain trade. Hence, an impatient ruler is willing to accept a lower lump-sum amount from the merchant in exchange of the grant of liberties.

In light of the offered rationale for political institutions, a final comment is dedicated to the role played by $M$ 's reservation utility. Recall that, absent political institutions, an efficient provision of market institutions at a cost $\underline{c}$ is ensured when M's reservation utility is null. In this case, political institutions do not play any role and, consequently, do not emerge. All else equal, higher levels of $M$ 's reservation utility increase both $R$ and $A$ 's temptation to coercively extract. The higher $M$ 's reservation utility, the more likely political institutions are to be granted.

In the following section we present historical evidence in support of the results highlighted in our formal model.

\section{Trade, Administration and Freedom Charters}

We argue that the dynamics of trade and political institutions in England (and part of Wales) between the eleventh and the thirteenth century make a case for our model. Table 1 below presents a chronology of the main events occurring in England

\footnotetext{
${ }^{48}$ The main result in Proposition 2, namely that political institutions are granted if and only if trade is relevant, would also hold in a richer setting in which political institutions amount to $R$ choosing the size of both $(i)$ the bureaucracy under $M$ 's control and (ii) the bureaucracy under her direct control. A formal proof is available from the authors upon request.
} 
during the period of interest (1066-1307).

Table 1: Major Events. England and Wales 1066-1307.

\begin{tabular}{|c|c|}
\hline Year & Fact \\
\hline 1066 & Norman Conquest / William the Conqueror \\
\hline 1087 & William II \\
\hline 1100 & Henry I (Coronation Charter) \\
\hline $1130-31$ & Charters of Lincoln and London \\
\hline 1135 & Stephen of Blois \\
\hline $1139-1154$ & Civil war \\
\hline 1154 & Henry II \\
\hline $1169-70$ & Inquest of the Sheriffs \\
\hline 1189 & Richard I / Third Crusade \\
\hline $1192-94$ & End of the Crusade - Return of Richard to England \\
\hline 1194 & The Iter of 1194 - Election of the coroner \\
\hline 1199 & John \\
\hline 1202 & War with France breaks out \\
\hline $1215-17$ & Magna Charta - First Barons' War \\
\hline 1216 & Henry III (minor) \\
\hline 1227 & Henry III \\
\hline $1258-59$ & Provisions of Oxford - Westminster \\
\hline $1263-1267$ & Second Barons' War \\
\hline $1266-67$ & Dictum of Kenilworth - Statute of Marlborough \\
\hline 1272 & Edward I \\
\hline $1274-1275$ & Inquiry \\
\hline 1275 & First Parliament / Statute of Westminster I \\
\hline 1277 & First Welsh War \\
\hline $1282-83$ & Second Welsh War \\
\hline 1285 & Statute of Westminster II (chapter 13) \\
\hline 1296 & First War of Scottish Independence breaks out \\
\hline 1307 & Death of Edward I \\
\hline
\end{tabular}

Revival of Trade. Tenth century Europe is feudal. Society is essentially divided between those who fight (kings and landlords), pray (churchmen), and work the land 
(peasants). ${ }^{49}$ Much of the economy is rural and trade is local. However, by the turn of the eleventh century, an impressive revival of trade, which had been at its minimal level since the collapse of the Roman Empire, takes place, particularly along the trade routes linking Northern Italy to the flourishing ports situated in the Low Countries (e.g. Bruges). By the end of the tenth century trade also spreads to England, and especially to London (Ballard [1904], pag. 116). The Norman Conquest (1066) fosters trade (Tait [1936], pag. 136), and the great inquest into royal domains launched in 1086 and leading to the compilation of the Domesday Book, shows a transition from a barter-economy to a money one (Ballard [1904], pag. 77).

Traded commodities, to name only a few, include wool (England), clothes (Flanders) and wine (Gascony). ${ }^{50}$ From this stems a new social class, the merchants, and with it an increased importance of payments in money (as opposed to kind), as well as a higher demand for contract enforcement and protection. ${ }^{51}$

Trade occurs within fairs (e.g. Champagne, Lyon, St. Yves) and towns. The latter, which for long had been mainly used for defensive (fortifications) and religious purposes, now flourish (Maitland [1897] pag. 196). New ones are founded. Towns become "nonfeudal" elements within a feudal society (Finer [1997]). Active within these, merchants are free men in that they are allowed to trade and move, and are not tied to a lord. ${ }^{52}$

Local Administration and the King's Revenues. The local fiscal and judicial administration of England in the eleventh century is based on a strictly hierarchical topdown structure. The king appoints local officials on the royal domain. These, known

\footnotetext{
${ }^{49}$ For an analysis of the feudal society see Bloch [1964].

${ }^{50}$ See Tait [1936] pag. 131-133 for examples of traded commodities in England.

${ }^{51}$ According to North and Thomas [1973], this increase in commercial activities leads to formal agreements replacing informal (or relational) ones. For a formal model see Dixit [2003].

52" City air makes you free" was a contemporary say in Germany. Free men held property (burgage tenement) and could freely alienate it. On burgage tenure in England see Ballard [1913], and Ballard and Tait [1923]. In the following we will use the words town, city and borough interchangeably. The same is true of the corresponding definitions of townsmen, citizens and burgesses.
} 
as sheriffs, are empowered with judicial and fiscal authority in the shire. Within towns, officials in charge of performing these duties take the name of reeves (or bailiffs), and are appointed by either the king or the sheriff. ${ }^{53}$ Royal officials enforce the law in the courts of the time, known as the shire-courts, the hundred-courts, and the boroughcourts. Officials are also in charge of collecting the king's revenues.

Sources of revenues accruing from towns to the king, and different from the occasional gifts (aids, tallages), are constituted by the geld (a land tax), the gablum (a revenue from the king's demesne houses), market tolls, receipts from mints, and amends and forfeitures of the profits of justice (Ballard [1904], pag. 63-64). Receipts from markets are estimated as being among the largest sources of revenues (Ballard [1904], pag. 90-91). The sum of these revenues constitute the farm of the borough, for which the sheriff is held accountable to the king's treasury (the Exchequer).

Local Officials' Exactions. The contractual arrangement between the king and his official is known as tax farming: the king sells the sheriff the right to collect his revenues (among which figures profits from justice) in return for an agreed upon fixed sum. The official can then retain any exceeding sum he is able to extract from his jurisdictional area. This arrangement, perhaps not surprisingly, gives strong incentives for local officials to engage in predatory behavior (Stubbs [1905]). The scotale is a particularly well-known practice employed by sheriffs to extract payment from townsmen. ${ }^{54}$ Other extortionary practices take the form of forced billeting, purveyance, forced loans, and the impleading of burgesses without an accuser or a witness. ${ }^{55}$

These practices give rise to complaints (clamores) by townsmen in the twelfth century, not only England but in Western Europe in general (Bisson [2008]). During the

\footnotetext{
${ }^{53}$ For a thorough analysis of the English administration system in the period of interest see Ballard [1904], Stubbs [1905], Ballard [1913], and Green [1986].

${ }^{54}$ See Ballard [1904], pag. xlvii-xlviii, and Stubbs [1905], pag. 703.

${ }^{55}$ Ballard [1904], pag. xlvii-xlviii, and pag. lxxxv-lxxxvi.
} 
reign of William Rufus, local officials act in a rapacious manner under the rule of chief minister Bishop Ranulf Flambard (Stubbs [1905], pag. 342-343). Henry I, intentioned to put exactions to an end, appoints Bishop Roger of Salisbury as chief minister. His work is directed toward the creation of a routine-based bureaucracy. Eradicating coercive manners is however not an easy task:

Reflecting back on this time, in what seem to be his own words, Henry of Huntingdon put it generally and strongly: "Sheriffs and reeves, whose office was justice and judgment, were more terrible than thieves and plunderers, and more savage than the most savage." [...] One is reminded of the Peterborough chronicle which, in its entries for 1094-1105, has a relentless indictment of fiscal rapacity by kings' men. ${ }^{56}$

Although justice is administered for profits, royal sheriffs exploit it to extract even higher fees. The consequences over the functioning of courts are disastrous: in the course of the twelfth century the king orders that courts should be held only once a week "to prevent burgesses being harassed by too frequent sittings" (Ballard [1913], pag. lxii).

First Attempts at Limiting Local Officials' Exactions. The reigns of Henry II (1154-1189) and Richard I (1189-1999) mark an important change in policy with respect to royal control over officials. In 1170 Henry II launches the Inquest of the Sheriffs: sheriffs are investigated by royal justices for their alleged extortionary behavior during the collection of the gift from towns in provision of the king's daughter's wedding (116869). Seventeen or more sheriffs are displaced and their authority is curbed. In 1194, itinerant royal justices are sent into the shires to further investigate their behavior. The Iter of 1194 results in the enactment of important provisions; in particular it is

\footnotetext{
${ }^{56}$ Bisson [2008], p. 178 , and p. 330.
} 
provided that sheriffs shall no more be justices in their own counties. Furthermore, the elected office of the coroner is created as a further check on the sheriffs' judicial power. Coroners are in charge of keeping pleas of the Crown. ${ }^{57}$ In 1195 the sheriff is further discharged from the duty of receiving the oath of peace, his duty now consisting only of receiving and keeping criminals until the coming of the justices. ${ }^{58}$

In 1215, the Magna Charta (chapter 24) specifically deals with (and restricts) sheriffs' jurisdictional powers (Merewether [1835], pag, 429). Remarkably, the barons request that "sheriffs shall no longer meddle with the pleas of the Crown, without the coroners" (Stubbs [1905], pag. 601, pag. 680).

Charters. Launching inquests by means of itinerant royal justices is not the only way twelfth century English kings attempt to keep their officials' behavior in check. In 1130, Henry I grants the citizens of Lincoln a Charter containing the right to "hold their city in chief of the king" in exchange of two-hundred marks of silver and four of golds (Stubbs [1905], pp. 164). This constitutes the first documented appearance of the firma burgi: the town (borough) is farmed to burgesses directly rather than to the sheriff or any other appointed tax farmer. The charter grants burgesses the right to collect the fixed yearly sum (farm) to be paid to the king's treasury. The same rights are granted to London in 1131. There, along with the farm of the city, citizens also explicitly obtain the right to elect the sheriffs for London and Middlesex. These are the only two cases of farms granted by Henry I.

Figure 1 below presents a chronology of the grants of the firma burgi to royal and mesne towns - i.e. towns which are not under the control of the king - occurring in England during the period 1130-1216. These are new grants: neither confirmations of

\footnotetext{
${ }^{57}$ According to Merewether [1835] (pag. 460), the coroner is established as a restraint on extortions perpetrated by the sheriffs.

${ }^{58}$ Stubbs [1905] pag. 568-569, pag. 680.
} 
old grants nor grants to towns which had been their liberties previously revoked are accounted for in Figure 1.

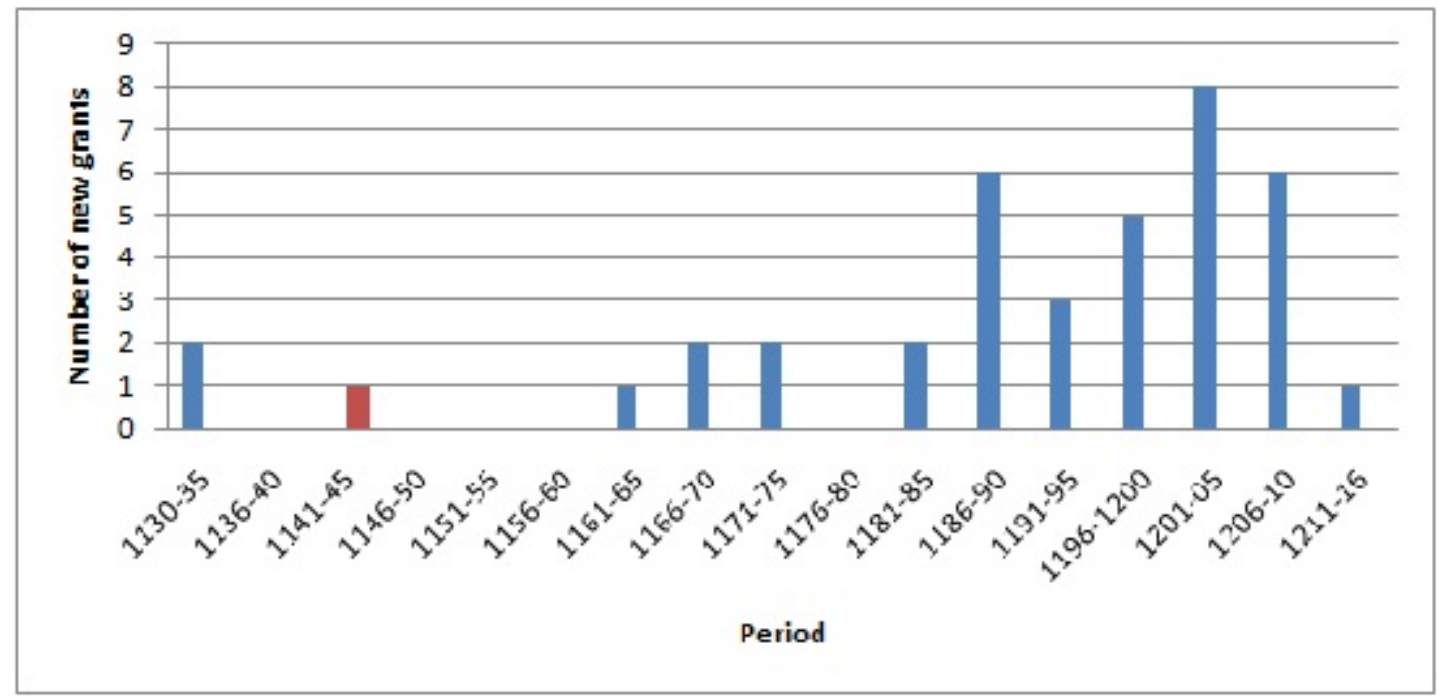

Figure 1: Grants of Firma Burgi to Royal and Mesne Boroughs: period 11301216.

Legend: Blue: Royal Boroughs - Red: Mesne Boroughs. Sources: Ballard [1913], Tait [1936].

Notes: No grants are documented before 1130. In some cases we do not have a certain date for the grant of the charter. However we do have a period within which the charter has been granted. We have adopted the procedure of selecting the middle year as a date for the charter. The interested years for royal boroughs are: 1172 (2 charters: 1154-89), and 1207 (1 charters: 1186-1227); for mesne boroughs we have 1141 (1 charter: 1137-45).

After the turbulent reign of Stephen (1135-1154), in which a Civil War breaks out, the grant of liberties is resumed by Henry II (1154-1189). During this reign seven additional boroughs receive the same kind of liberties through the granting of charters, namely Gloucester, Wallingford, Grimsby, Northampton, Bridgenorth, Shrewsbury, and Cambridge. ${ }^{59}$ According to Tait [1936] (pag. 174), the grant of liberties to Shrewsbury and Bridgenorth is possibly connected with the Inquest of 1169-70. These liberties are

\footnotetext{
${ }^{59}$ Ballard [1913], pag. cxxxviii-cxlvii, Tait [1936], pag. 176. On his French domain, Henry II grants the right to a (more) independent system of administration and jurisdiction important commercial to Rouen and La Rochelle. This system, known as the Etablissement de Rouen, is extended to many towns in the course of the twelfth and thirteenth century (e.g. Bordeaux, Bayonne) (Giry [1883]).
} 
nevertheless revocable. London sees its prerogatives being withdrawn during this reign. This is also true of Gloucester, to which liberties are revoked in 1169-70 after having attempted to form a commune (Tait [1936], pag. 176-177).

Richard I and John are even more prone to granting Charters. Their pressing need for money plays an important role: grants by Richard in 1189 are spurred by the need to raise money for the Third Crusade. Similarly, grants by John are urged by his need to finance the war with the French king breaking out in $1202 .^{60}$

Towns pay in order to be granted liberties, and often agree to pay an increment on the yearly farm previously paid by the royal sheriff. ${ }^{61}$ By the end of this period (1216), we register 37 grants among circa 145 royal boroughs (even though some of them no longer possess these prerogatives by the arrival of the Magna Charta). ${ }^{62}$ We view the towns' eagerness to pay to have sheriffs be withdrawn from their walls as further evidence of local officials' misbehavior.

In this period, two changes occur concerning the nature of the granted liberties. First the farm becomes perpetual, although still subject to revocation. In 1190 York is farmed by the citizens: liberties are however revoked six months later upon citizens reneging on the payment promised to the king (Tait [1936], pag. 179) ${ }^{63}$ Second, many charters explicitly grant the right of electing boroughs' officials in charge of financial and judicial administration (e.g. reeve, coroner). ${ }^{64}$ However, according to Ballard and Tait, this is not an additional right as towns enjoy it upon the grant of the firma burgi,

\footnotetext{
${ }^{60}$ See Stubbs [1905], pag. 698-699, and Tait [1936], pag. 176-177.

${ }^{61}$ See Tait [1936] pag. 184 for data on the amount of the farm and the increment paid by boroughs in the period 1066-1199.

${ }^{62}$ See Table 2 below. Our main data sources on liberties granted to towns for the period 1066-1216 are Ballard [1913] and Tait [1936].

${ }^{63}$ During the reign of Richard I, liberties are withdrawn from Lincoln, Cambridge and Southampton (Tait [1936], pag. 176-180).

${ }^{64}$ For instance, see the Charter granted by John to the burgesses of Ipswich in 1200 . The grant of liberties may also involve the election of bureaucrats more directly in charge of the enforcement of commercial contracts. In 1286 Henry III grants to the citizens of London the right to appoint four or five of their number to try "pleas of merchandise" (Gross [1906], p. 239).
} 
whether it is explicitly stated in the charter or not. ${ }^{65}$

A deeper investigation of the content of the charters of liberties sheds light on one of their main purposes. Townsmen are eager to gain control over the financial and judicial machinery of the town so as to exclude the jurisdiction of the sheriff. ${ }^{66}$ This is formally done by means of the non-intromittat clause: townsmen have the right to be subjected to the Borough court only, which is itself run by elected officers. Sheriffs (running the shire-court) lose jurisdiction over towns. ${ }^{67}$

Subsequent to the baronial revolt and the Magna Charta, the grant of liberties to towns is resumed by Henry III and Edward I. Less important towns are however concerned by this new wave of grants as major towns already possess liberties (Ballard and Tait [1923], pag. lvi).

Figure 2 below presents a chronology of the grants of the firma burgi to royal and mesne towns occurring in England during the period 1217-1307. These are new grants: neither confirmations of old grants nor grants to towns which had been their liberties previously revoked are accounted for in Figure 2.

The relative weakness of the Crown in the years preceding the Provisions of Oxford and the baronial revolt led by Simon de Montfort in 1263 plays a role during the grants of the years 1255-57. Importantly, these grants include the right for towns to return royal writs: this right acts as a further restraint on sheriffs' jurisdiction, as they are no longer allowed to enter the town to enact royal orders. ${ }^{68}$

Royal appointed officials do not cease to be a problem. In 1274-75 Edward I launches an Inquiry in order to investigate their behavior. In 1285 the Statute of Westminster II is passed, containing provisions concerning extortions perpetrated by

\footnotetext{
${ }^{65}$ See Ballard [1913], pag lxxxvi-lxxxvii, and Tait [1936], pag. 186.

${ }^{66}$ Merewether [1835], pag. 124, and pag. 467. Ballard [1904], pag. 91-93. See also Stubbs [1905], pag. 482, and pag. 699-700.

${ }^{67}$ See Ballard and Tait [1923], pag. lxi. See also Ballard [1913].

${ }^{68}$ Ballard and Tait [1936], pag. xvii-xviii. Rather than judicial writs, towns are anxious to enact the ones related to the summons of the Exchequer (Ballard and Tait [1936], pag. lxii-lxiii).
} 


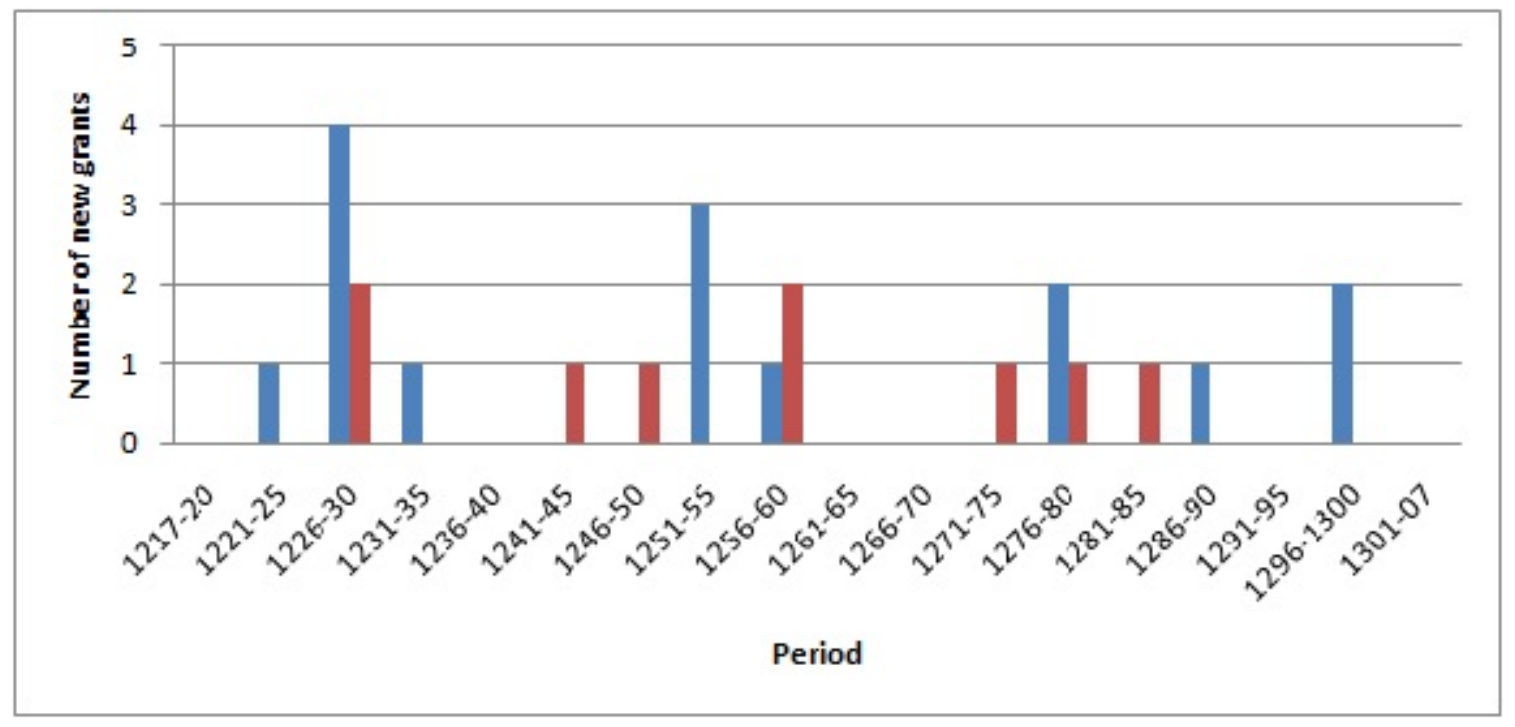

Figure 2: Grants of Firma Burgi to Royal and Mesne Boroughs: period 12171307.

Legend: Blue: Royal Boroughs - Red: Mesne Boroughs. Sources: Ballard [1913], Ballard and Tait [1923].

Notes: In some cases we do not have a certain date for the grant of the charter. However we do have a period within which the charter has been granted. We have adopted the procedure of selecting the middle year as a date for the charter. The interested year for royal boroughs is 1278 ( 1 charter: 1262-93); for mesne boroughs we have 1279 ( 1 charter: 1277-82), and 1282 (1 charter: 1272-91).

the sheriffs (chapter 13). Edward I's charters are still motivated by the wish to restrain officials' behavior. ${ }^{69}$ An additional office also arises: some towns are allowed to elect mayors. ${ }^{70}$ This figure symbolizes the autonomy of the town (Reynolds [1977] pag. 108-109, Reynolds [2004]). According to Tait [1936], mayors come along with the right for townsmen to impose taxes on themselves for municipal purpose. ${ }^{71}$

\footnotetext{
${ }^{69}$ Merewether [1835], pag. 488-490. During this period many towns see their liberties revoked: for instance Dunwich in 1268 and 1293, Ipswich in 1284 and 1291, Newcastle-upon-Tyne in 1294, Norwich in $1281 \mathrm{~m}$ Nottingham in 1284 (Merewether [1835], pag. 464, pag. 512-513, pag. 524-529).

${ }^{70}$ But see our discussion on the London commune and the election of a mayor in the last decade of the twelfth century. The mayeur is present in fourteenth century Flanders also. The mayeur is nominated by the echevins (Giry [1877], p. 171).

${ }^{71}$ Tait [1936], p. 298.
} 
Towns not under Direct Control of the King. As Figure 1 and 2 show, if kings in England are willing to grant growing liberties to towns during the course of the twelfth and thirteenth century, the same seems not to be true of local lords collecting tolls and administering justice in the mesne towns. ${ }^{72}$ These towns are rarely farmed by the burgesses (Tait [1936], pag. 191). Of the sample of circa 120 mesne towns we document, only one (namely Richmond in 1137-45) is put at farm by 1216 (Ballard [1913], pag. lxxix). By the end of the period of interest (1307), we document 11 grants in total among mesne towns (see Table 2$).{ }^{73}$

Mense lords seem more prone to grant the right to elect an officer (most of the times a reeve) though. In the period following the first baronial revolt (1215-17), we document 22 such grants in boroughs not farmed by their burgesses. The grant of the right to elect a reeve is similar but narrower in scope with respect to the firma burgi, which gives right to appointment of different types of local officials. In general, kings appear to rely significantly more on the grant of the borough at farm rather than on the grant of election rights over single officials.

Table 2 shows a summary of the number of farms granted by overlords to burgesses in the period of interest. Our data on the liberties granted to boroughs are mainly in Ballard [1913] for the period 1066-1216, and in Ballard and Tait [1923] for the period 1216-1307. We integrate these data with the work by Merewether [1835] and Tait [1936]. Moreover, these works however only contain a list of boroughs that are granted charters in the period of interest. We integrate these list by adding all the towns listed

\footnotetext{
${ }^{72}$ During the period of interest some of the royal towns are mediatized, i.e. they are held both by the king and a (local) lord, most of the times an Earl. In this case each tax recipient employs his own officials to collect taxes. According to the third-penny rule, the Earl has the right to collect a third of the borough's revenues. We know of no charters granted by an Earl having rights to the third penny. See Ballard [1904], pag. 37.

${ }^{73}$ Table 2 does not take the grant to Helston into account as it seems to be a royal borough at the time of the first grant.
} 
Table 2: Boroughs and Farms by Burgesses. England and Wales 1066-1307

\begin{tabular}{|c|ccc|}
\hline \hline Period & Royal & Mesne & Uncertain \\
\hline \hline & \multicolumn{3}{|c|}{ Number of Boroughs } \\
\hline $1066-1216$ & 145 & 119 & 6 \\
& & 122 & 6 \\
$1216-1307$ & 144 & 1 & 0 \\
& \multicolumn{3}{|c|}{ Number of Farms to Burgesses } \\
\hline $1066-1216$ & $37\left(^{*}\right)$ & $10\left(^{*}\right)$ & 0 \\
$1216-1307$ & $16\left(^{* *}\right)$ & Ballard & \\
\hline \hline
\end{tabular}

Sources: Merewether [1835], Maitland [1897], Ballard [1904], Ballard [1913], Usher [1920], Ballard and Tait [1923], Stephenson [1933], Tait [1936].

Notes: Liverpool and Newcastle-under-Lyme are listed as Royal Boroughs in the period 10661216, and as both Royal and Mesne Boroughs in the period 1216-1307. Helston is listed as a Royal Borough in the period 1066-1216, and as a Mesne Boroughs in the period 1216-1307. The number of listed farms are new grants only.

$(*)$ : Helston is granted at farm to burgesses by the king in 1201, and by a Mesne lord in 1260 .

$(* *)$ : Helmsley is granted at farm in circa 1186-1227: we include the farm in the period 1216-1307. Also, Ballard and Tait [1923] list Helmsley, Newport (Isle of W.) and Sheffield as Mesne boroughs at the beginning of the period 1216. Tait [1936] however does not include them among the Mesne boroughs at farm. Also, according to Merewether [1835] (pag. 45859 ), Bristol is farmed to its burgesses in 1226, but we have no confirmation of this grant in Ballard and Tait [1923]; therefore, we do not include it among the royal boroughs at farm.

in the Domesday Book (1086) (available in Ballard [1904]). ${ }^{74}$ Also, we add boroughs listed by Usher [1920], Stephenson [1933] and Tait [1936].

Table 3 shows a summary of the boroughs which are granted the right to elect an officer (usually a reeve, but coroners and mayors are also included). As in Table 2, we distinguish between Royal and Mesne boroughs, and we divide our period of interest in two subperiods. ${ }^{75}$

As Table 2 makes clear, grants of boroughs at farm to their burgesses by mesne lords are less numerous and arrive at a later point in time. The last recipient of taxes (i.e. the mesne lord) being closer, misbehavior by the appointed official is less likely to be a problem. This removes one of the main functions charters accomplish. Also, boroughs

\footnotetext{
${ }^{74}$ Bruton and Seasalter are excluded from the list of boroughs as they lose their (borough-)status shortly after the compilation of the Domesday Book.

${ }^{75}$ The list of boroughs and liberties provided by Ballard [1913] and Ballard and Tait [1923] distinguished between Royal and Mesne boroughs. A complete dataset is available from the authors upon request.
} 
Table 3: Officers Elected and Non-intromittat Clause. England and Wales 1066-1307.

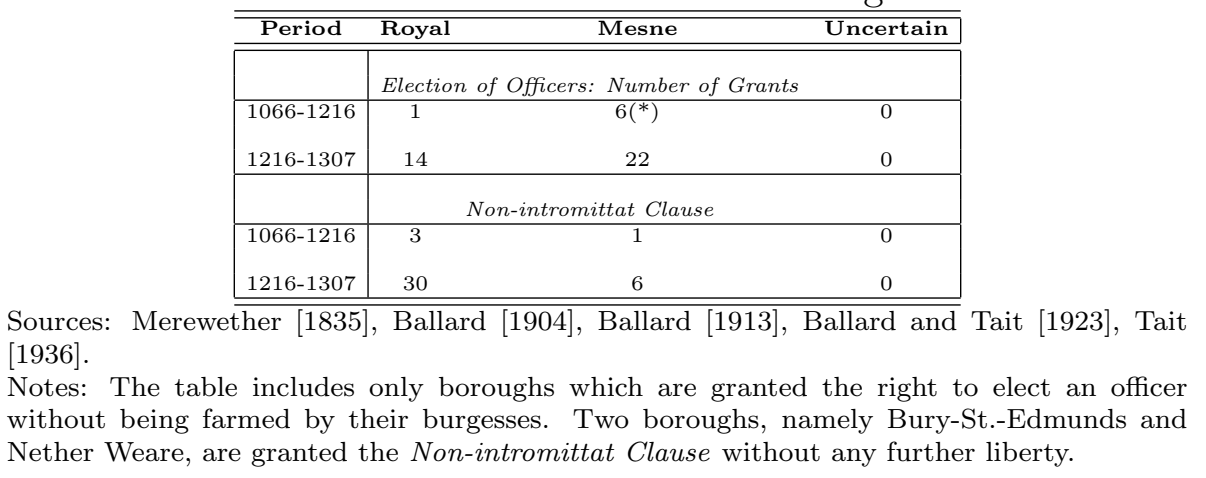

in the hands of local lords are mostly small and with no trade connection, which further lowers the scope for employing officials in charge of enforcing the (merchant) law. ${ }^{76}$

In 1292 the citizens of Liverpool have reasons to complain in answer to a writ Quo Warranto: "they explained that at present they had no bailiff of their own (de se), Earl Edmund of Lancaster, their lord since 1266, having put in bailiffs of his own appointment and prevented them from having a free borough". As in Liverpool, Newcastle-under-Lyme becomes under direct control of the mesne lord's and sees its liberties - previously granted by the king - immediately revoked. ${ }^{77}$ At Leicester, probably the largest of the mesne towns, reeves are elected in 1276-77 only. The burgesses of Leicester are granted the (revocable) right to farm the lord's revenues in $1375 .^{78}$

Our historical account shall stop at this point. To sum up, chartered towns have spread throughout all the English territories (mostly between the twelfth and the thirteenth century) following the revival of trade, and in response to widespread arbitrary malfeasance by rulers' officers. Rural manors also are sometimes granted the farm

\footnotetext{
${ }^{76}$ On seigneurial boroughs' trade connection see Ballard and Tait [1923], pag. lxxxii.

${ }^{77}$ Ballard and Tait [1923], pag. lvi.

${ }^{78}$ Tait [1936], pp. 191-192.
} 
and/or the right to elect reeves by the overlord. ${ }^{79}$ However bailiffs and stewards do not cease to be appointed by the lord as a check on elected reeves and constables (Usher [1920], pag. 128-130). Charters made towns more autonomous and, therefore, less exposed to coercive exactions. Urban liberties in England reach a complete structure by the fourteenth century (Reynolds [1977]). Arguably, the early autonomy granted to towns in England, along with the expansion of trade and the need to wage wars, played a role in the creation of nation wide representative assemblies. ${ }^{80}$

\section{Conclusions}

In this paper we propose a novel and formal theory linking the rise of trade to the joint evolution of political and market institutions. In order to provide law enforcement (i.e. market institutions) for the citizenry to produce and trade, a ruler (i) heavily invests in a bureaucracy capable of coercion and (ii) creates a system of peaceful taxation. Such a high investment however potentially paves the way to coercive expropriation by bureaucrats. By delegating control over the bureaucracy to the (naturally) better informed citizenry - say the merchant class - the ruler lowers the cost of investing in market institutions. By means of political institutions society achieves a more efficient level of law and order.

Absent the need to provide law and order - say absent gains from trade - a ruler does not find it profitable to relinquish power to the citizenry: citizens' informational advantage is not valuable to the ruler as she can keep the bureaucracy's behavior in check via controlling its size. Furthermore, delegation to the citizens improves their

\footnotetext{
${ }^{79}$ See Tait [1936], pag. 251. However we have no detailed information neither on their number nor on the time of the arrival of such liberties.

${ }^{80}$ See Stasavage [2011] for the role played by war financing (and sovereign debt in general) in the birth and evolution of nation wide representative assemblies. See Willard [1934] and Hodgett [2006] on the evolution of taxation in England in the thirteenth and fourteenth century. See Finer [1997] for the history of Parliaments in England, France and Spain.
} 
ability to escape taxation.

We motivate our formal theory by investigating the institutional dynamics in postNorman Conquest England. Eleventh century England is feudal: political power is concentrated in the hands of territorial lords, either the king or a local seigneur. In parallel with the rise of trade, power-holders develop a system of law enforcement by hiring increasingly numerous local officials. This change however goes hand in hand with episodes of extortionary behavior by appointed officials. In their effort to restrain misbehavior, kings develop systems of auditing. Eventually, by the middle of the twelfth century, kings increasingly give in to the citizens' desire of (limited) self-governance. By means of Charters, rulers grant citizens the right to farm their town, which formally amounts to the right of appointing and firing local law enforcers and tax collectors.

Although this spread of liberties is fostered by the rulers' need to wage wars, we document that control over local officials is an important determinant of the dynamics of political and market institutions. Overlords distant from tax collection points (e.g. the king) are for instance more prone to delegate authority to towns than local lords.

In this paper our ambition was to provide a rationale for a fundamental historical evolution of institutions in England. In so doing we offer a new perspective on the potential role played by trade in shaping political and market institutions. By letting citizens handle the local bureaucracy themselves, a more efficient and stronger bureaucracy can be sustained at a lower cost. The consequent higher supply of law and order in turn implies a higher creation of wealth. 


\section{Appendix 1}

This Appendix includes the implications of the technical assumption A1 and all the proofs.

Technical Assumption: A1 implies the existence of the following threshold in a trade economy: given $\forall \underline{u}_{M} \in(0, \underline{y})$,

$$
\exists \widehat{q}\left(\underline{u}_{M}\right): y(q) \leq f(q)+\underline{u}_{M},
$$

for $q \geq \widehat{q}\left(\underline{u}_{M}\right) .{ }^{81}$ We have $\widehat{q}\left(\underline{u}_{M}\right)$ non-increasing in $\underline{u}_{M}$. Unless needed, we suppress the argument $\underline{u}_{M}$ when referring to $\widehat{q}\left(\underline{u}_{M}\right)$.

Proof. Proposition 1: Consider $I=R$. The surplus' maximizing quantity $q^{*}(\underline{c})$ is given by the FOC: ${ }^{82}$

$$
y_{q}(q)=\underline{c}
$$

Define now:

$$
q^{\max }=\arg \max _{\left\{q \in \mathbb{R}_{+}\right\}} y(q)-f(q),
$$

as the quantity that maximizes $U$ when $\widetilde{T}(q)=f(q)$. A1 ensures the existence of a unique $q^{\max }$. In a manorial economy we have $q^{*}=q^{\max }=0$.

We divide the analysis by distinguishing a manorial from a trade economy. Consider first a manorial economy in which $y(q)=\underline{y}$. The solution to $R$ 's problem, defined as

\footnotetext{
${ }^{81}$ The equality holds for $q=\widehat{q}\left(\underline{u}_{M}\right)$.

${ }^{82}$ When referring to the functions $y(q)$ and $f(q)$, subscripts indicate the derivative with respect to the argument of the function.
} 
$q^{s}(\underline{c})$, is given by:

$$
\begin{gathered}
\max _{\left\{q \in \mathbb{R}_{+}\right\}} f(q)-\underline{c} q, \\
\text { s.t. } \underline{y}-f(q) \geq \underline{u}_{M} .
\end{gathered}
$$

It is straightforward to show that we generally have an over-investment in $q$ with respect to the efficient level, i.e. $q^{s}(\underline{c})>q^{*}=0$.

Now consider $R$ 's maximization problem in a trade economy. The solution to $R$ 's problem, still defined as $q^{s}(\underline{c})$, is given by:

$$
\begin{aligned}
& q^{s}=\arg \max _{\left\{q \in \mathbb{R}_{+}\right\}} f(q)-\underline{c} q, \\
& \text { s.t. } y(q)-f(q) \geq \underline{u}_{M},
\end{aligned}
$$

where A1-A2 imply that the solution to this problem is constrained, with $\widehat{q}<q^{*}(\underline{c})$. In order to verify PC, $R$ distorts her optimal choice of $q$ by moving her investment toward $q^{\max }$ (i.e. $R$ decreases her investment). In this case $R$ sets $q^{s}=\widehat{q} \geq q^{\max }$.

To summarize, $R$ 's investment as a function of the type of economy considered is given by:

- $q^{s}(\underline{c}) \geq q^{*}=0$ if a manorial economy;

- $q^{s}(\underline{c}) \leq q^{*}(\underline{c})$ if a trade economy.

When considering the political institutional choice, since taxation is equal to coercive extraction, political institutions do not affect the cost of inducing coercive extraction. Therefore $R$ never finds it profitable to grant political institutions. In fact, if $R$ were to set $I=M, M$ would optimally sets $q_{M}^{s}(\underline{c})=q^{*}(\underline{c})$ and makes a zero transfer $\left(t_{M}=0\right)$ to $R$ independently of the type of economy considered. 
Proof. Lemma 1: Consider the case in which $\widetilde{t}>f(\widetilde{q})$. This implies that $\widetilde{q}<q^{\diamond}(\widetilde{t})$. Therefore the cost of hiring each single officer is equal to $\underline{c}$. The only case we need to investigate is the one in which $\min [y(\widetilde{q}), f(\widetilde{q})]=f(\widetilde{q})$. We have:

$$
[f(\widetilde{q})-\underline{c} \widetilde{q}]+\frac{\beta_{R}}{1-\beta_{R}}\left[f\left(q^{s}\right)-\underline{c} q^{s}\right]<[\widetilde{t}-\underline{c} \widetilde{q}]+\frac{\beta_{R}}{1-\beta_{R}}\left[f\left(q^{s}\right)-\underline{c} q^{s}\right]
$$

Moreover, from $\mathbf{P C}(R)$ we also have:

$$
[\widetilde{t}-\underline{c} \widetilde{q}]+\frac{\beta_{R}}{1-\beta_{R}}\left[f\left(q^{s}\right)-\underline{c} q^{s}\right] \leq \frac{[\widetilde{t}-\underline{c} \widetilde{q}]}{1-\beta_{R}}
$$

then, by combining the two inequalities, we obtain:

$$
[f(\widetilde{q})-\underline{c} \widetilde{q}]+\frac{\beta_{R}}{1-\beta_{R}}\left[f\left(q^{s}\right)-\underline{c} q^{s}\right]<\frac{[\widetilde{t}-\underline{c} \widetilde{q}]}{1-\beta_{R}},
$$

that is, we recover $\mathbf{I C C}(R)$.

Conversely, consider the case in which $\widetilde{t} \leq f(\widetilde{q})$ instead. Assume $\min [y(\widetilde{q}), f(\widetilde{q})]=$ $f(\widetilde{q})$. When $\mathbf{I C C}(R)$ holds we have:

$$
\frac{[\widetilde{t}-C(\widetilde{t}, \widetilde{q})]}{1-\beta_{R}} \geq[f(\widetilde{q})-\underline{c} \widetilde{q}]+\frac{\beta_{R}}{1-\beta_{R}}\left[f\left(q^{s}\right)-\underline{c} q^{s}\right] \geq[\widetilde{t}-\underline{c} \widetilde{q}]+\frac{\beta_{R}}{1-\beta_{R}}\left[f\left(q^{s}\right)-\underline{c} q^{s}\right],
$$

and where:

$$
[\widetilde{t}-\underline{c} \widetilde{q}]+\frac{\beta_{R}}{1-\beta_{R}}\left[f\left(q^{s}\right)-\underline{c} q^{s}\right] \geq[\widetilde{t}-C(\widetilde{t}, \widetilde{q})]+\frac{\beta_{R}}{1-\beta_{R}}\left[f\left(q^{s}\right)-\underline{c} q^{s}\right]
$$

These two chains of inequalities finally give:

$$
\widetilde{t}-C(\widetilde{t}, \widetilde{q}) \geq\left[f\left(q^{s}\right)-\underline{c} q^{s}\right],
$$


i.e. we recover $\mathbf{P C}(R)$. When $\min [y(\widetilde{q}), f(\widetilde{q})]=y(\widetilde{q})$, it is straightforward to show that the inequality continues to hold.

Also the same reasoning holds if $y(\widetilde{q})=\underline{y}$.

Proof. Lemma 2: Let us define the solution to (13) in terms of both the transfer and the investment as $\left\{t^{r}, q^{r}\right\}$ (where $r$ stands for repeated). From this FOC it is clear that we have:

- $q^{r} \in[0, \check{q}(\underline{c})]$ and

- $t^{r}=\beta_{M}\left[\underline{y}-U^{s}\right]+\left(1-\beta_{M}\right) f\left(q^{r}\right)$,

where $U^{s}$ is $M$ 's utility in the one-period game, and where $\check{q}(\underline{c})$ is defined as the solution to $R$ 's one-period problem when $\mathbf{P C}$ is disregarded, i.e.:

$$
\check{q}(\underline{c})=\arg \max _{\left\{q \in \mathbb{R}_{+}\right\}} f(q)-\underline{c} q .
$$

Further recall that we have $q^{*}=0$.

We need to show that all the constraints hold. We define the solution to $R$ 's problem verifying all the constraints as $\left\{t_{R}, q_{R}\right\}$.

First we consider $\mathbf{P C}(R)$ and $\mathbf{I C C}(R)$. The proof for $\mathbf{P C}(R)$ is trivial. It is enough to observe that $R$ can choose $q=0$ : whenever $q_{R} \neq 0$ it has to be the case that she gets a higher payoff. Moreover, notice that we have $t^{r} \geq f\left(q^{r}\right)$ : then $\mathbf{I C C}(R)$ holds by Lemma 1.

We now turn to PC. Depending on the value of $\underline{c}$ we can have two cases: (i) $\check{q}(\underline{c}) \leq \widehat{q}$, and (ii) $\check{q}(\underline{c})>\widehat{q}$.

In case (i) we also have $q^{s}(\underline{c})=\check{q}(\underline{c})$. $\mathbf{P C}$ is rewritten as:

$$
\left(1-\beta_{M}\right)\left[\underline{y}-f\left(q^{r}\right)\right] \geq \underline{u}_{M}-\beta_{M} U^{s} .
$$


Since $q^{r}\left(\underline{c}, \beta_{M}\right) \in[0, \check{q}(\underline{c})]$ it is easily checked that $\mathbf{P C}$ holds. This follows immediately from the fact that the RHS in the previous inequality is lower (or equal) than (1$\left.\beta_{M}\right) \underline{u}_{M}$.

Consider now case (ii). We have $q^{s}=\widehat{q}$. Then $\mathbf{P C}$ is rewritten as:

$$
\left(1-\beta_{M}\right)[\underline{y}-f(q)] \geq\left(1-\beta_{M}\right) \underline{u}_{M},
$$

implying that $\mathbf{P C}$ holds iff $q \leq \widehat{q}$. Two subcases can arise:

- $q^{r}\left(\underline{c}, \beta_{M}\right) \leq \widehat{q}$. Then $q_{R}=q^{r}\left(\underline{c}, \beta_{M}\right)$; or

- $q^{r}\left(\underline{c}, \beta_{M}\right)>\widehat{q}$. Then $q_{R}=\widehat{q}$ so as to verify PC.

In the second case all the constraints hold as equalities. This finally establishes that $q^{r}\left(\underline{c}, \beta_{M}\right) \in\left[0, q^{s}(\underline{c})\right]$.

Finally, we have that the higher $\beta_{M}$, the closer $q^{r}(\cdot)$ to efficiency. To verify this last point, from (13) we have that:

$$
\frac{\partial q^{r}}{\partial \beta_{M}}=\frac{\frac{f\left(q^{r}\right)}{\partial q}}{S O C}<0
$$

where SOC stands for Second Order Condition.

Proof. Lemma 3: Let us define the constrained solution to $R$ 's problem as $q^{r}\left(\underline{c}, \bar{c}, \underline{u}_{M}, \beta_{R}\right)$. The unconstrained solution is defined as $q^{\circ}(\underline{c}, \bar{c})$.

From $\mathbf{P C}$ we have $t=y(q)-\underline{u}_{M}$. Therefore, we have $q^{\diamond}(t)=q^{s}=\widehat{q}$ in (4). ${ }^{83}$

Recall from (4) that the cost function has a kink at $q=\widehat{q}<q^{*}(\underline{c})$ (see Proposition 1). Given (4), we have that $q^{\circ}(\underline{c}, \bar{c})<q^{*}(\underline{c})$, where $q^{\circ}(\underline{c}, \bar{c})$ (also) maximizes the surplus when the cost of investing in the bureaucracy is given by (3). We have two main cases:

\footnotetext{
${ }^{83}$ Given A1, there are two solutions to the equality $y(q)-\underline{u}_{M}=f(q)$, namely $\widehat{q}^{l}$ and $\widehat{q}^{h}$. We focus on the highest root, since we have $t=y(q)-\underline{u}_{M}<f(q)$ for $q>\widehat{q}^{h}$.
} 
(i) $q^{\circ}(\underline{c}, \bar{c})>\widehat{q}$;

(ii) $q^{\circ}(\underline{c}, \bar{c})=\widehat{q}$.

Consider case (i). $R$ is interested in moving the investment away from $q^{s}=\widehat{q}$ toward $q^{\circ}(\underline{c}, \bar{c})$. We define $\bar{q}$ as the value of $q$ such that:

$$
y(q)=f(q)
$$

where $\bar{q}=\widehat{q}\left(\underline{u}_{M}\right)$ when $\underline{u}_{M}=0$.

Two subcases can occur, namely:

i.1 $\bar{q}>q^{\circ}(\underline{c}, \bar{c})$,

i. $2 \bar{q} \leq q^{\circ}(\underline{c}, \bar{c})$.

Consider first case i.1, i.e. we have $\min [y(q), f(q)]=f(q)$, for $q=\left\{\widehat{q}, q^{\circ}\right\}$. Then, when $q=q^{\circ}$, from (4) and the RHS in (11) we get:

$$
\bar{\beta}_{R}=\frac{\underline{u}_{M}-\left[y\left(q^{\circ}\right)-f\left(q^{\circ}\right)\right]+[\bar{c}-\underline{c}]\left(q^{\circ}-q^{s}\right)}{\left[f\left(q^{\circ}\right)-\underline{c} q^{\circ}\right]-\left[f\left(q^{s}\right)-\underline{c} q^{s}\right]} .
$$

If $\beta_{R} \geq \bar{\beta}_{R}, R$ binds $\mathbf{P C}$ and the solution $q_{R}=q^{\circ}(\underline{c}, \bar{c})$ verifies $\mathbf{I C C}(R)$. We then have $t_{R}=\left[y\left(q^{\circ}\right)-\underline{u}_{M}\right]$.

When $\beta_{R}<\bar{\beta}_{R}$, ICC $(R)$ binds. We write $\mathbf{I C C}(R)$ as:

$$
y(q)-\underline{u}_{M}-\underline{c} q^{s}-\bar{c}\left(q-q^{s}\right) \geq\left(1-\beta_{R}\right)[f(q)-\underline{c} q]+\beta_{R}\left[f\left(q^{s}\right)-\underline{c} q^{s}\right] .
$$

Recall that $y_{q}(q)<f_{q}(q)$ for $q \geq q^{\max }$, where $q^{\max }$ is defined in the proof of Proposition 1, and where $q^{\max } \leq \widehat{q}$ (from A1-A2). Also the solution to $R$ 's problem is not greater than $q^{\circ}(\underline{c}, \bar{c})$ and not lower than $\widehat{q}$ (since at $\widehat{q}$ all the constraints trivially hold). 
Hence, as we move $q$ downward, ceteris paribus the difference between the LHS and the RHS in (17) increases until verifying $\operatorname{ICC}(R)$. When $\operatorname{ICC}(R)$ binds we have $q_{R}=q^{r}\left(\underline{c}, \bar{c}, \underline{u}_{M}, \beta_{R}\right) \in\left[\widehat{q}, q^{\circ}(\underline{c}, \bar{c})\right]$, which is non-decreasing in $\beta_{R}$.

When considering case $\mathbf{i . 2}$, it is straightforward to show that the same procedure holds. The only difference consists in the fact that, when $\operatorname{ICC}(R), q$ has to be sufficiently lowered so that the area in which $\min [y(q), f(q)]=f(q)$ is reached.

Finally, in order to show that these outcomes are indeed the solution to this subgame (absent political institutions), we need to verify if the disregarded constraints hold.

We first check for $\mathbf{I C C}(M)$. By binding $\mathbf{P C}, \mathbf{I C C}(M)$ is given by:

$$
y(q)-\underline{u}_{M} \leq \beta_{M}\left\{[y(q)-f(q)]-\underline{u}_{M}\right\}+f(q),
$$

that is written as:

$$
y(q)-f(q) \leq \underline{u}_{M},
$$

that holds for $q \geq \widehat{q}$. Since the solution $q_{R}$ lies within the interval $\left[\widehat{q}, q^{\circ}(\underline{c}, \bar{c})\right], \mathbf{I C C}(M)$ holds.

Finally, $\forall q \in\left[\widehat{q}, q^{\circ}(\underline{c}, \bar{c})\right]$ we have $t=y(q)-\underline{u}_{M} \leq f(q)$. Therefore, by Lemma 1 $\mathrm{PC}(R)$ also holds.

When case ii is considered, the solution is trivially given by $q_{R}=\widehat{q}$.

Proof. Proposition 2: Let us start with the analysis of the Manorial economy, i.e. consider $y(q)=\underline{y}$. When $I_{\tau}=R, R$ incurs a cost $\underline{c}$ for hiring each single officer.

Let us define as $q_{M}$ the investment in the bureaucracy undertaken by player $M$ in period $\tau$ when $I_{\tau}=M$. Recall that, if $I_{\tau}=M, R$ cannot take political institutions back until period $\tau+1$. At the beginning of period $\tau+1, R$ can costlessly take political 
institutions back. Then, we show that $M$ cannot commit to repay $R$ a (per-period) sum so that she is indifferent between $I_{\tau}=M$ and $I_{\tau}=R$.

Our objective is to show that, when $I_{\tau}=M$ any movement toward efficiency generates a lower utility for $R$ with respect to the case in which $I_{\tau}=R$.

Consider the following two-phase strategy played by $R$. Cooperation phase: grant institutions in any period. Punishment phase: do not grant political institution and play the equilibrium of the finitely repeated stage game. $R$ starts with the cooperation phase in period $\tau$, and switches forever after to the punishment phase whenever $M$ transfers her a sum $t_{\tau}$ lower than $\underline{V}_{R}(\underline{c})=\left[t_{R}-\underline{c} q_{R}\right]$, where $\left\{t_{R}, q_{R}\right\}$ is given by Lemma $2 .^{84}$

If political institutions are taken back in any period $\tau$, play $Y_{\tau}=\underline{y}$ if $\underline{y}-f\left(q_{\tau}\right) \geq \underline{u}_{M}$, and play $Y_{\tau}=0$ otherwise.

In a manorial economy, the temptation to renege rests on $M$.

Consider then $I_{\tau}=M$. For $R$ to weakly prefer $I_{\tau}=M$ to $I_{\tau}=R, M$ has to commit to transfer $R$ the following sum:

$$
t_{M}(\underline{c}) \geq \underline{V}_{R}(\underline{c}) \equiv t_{R}-\underline{c} q_{R},
$$

where $\underline{V}_{R}(\underline{c})$ is $R$ 's per-period payoff when political institutions are not granted, and where the pair $\left\{t_{R}, q_{R}\right\}$ is given by Lemma 2 .

$M$ sustains the cost $\underline{c} q_{M}$ of investing in the bureaucracy (of size $q_{M}$ ) when granted political institutions. In order to prove that political institutions are not a profitable choice for $R$, we show that the strategy-pair above described can not induce $M$ to pay a transfer $t(\underline{c}) \geq \underline{V}_{R}(\underline{c})$ to $R$ in any period $\tau$.

First notice that $R$ can not deviate at any stage. Given the above-mentioned strate-

\footnotetext{
${ }^{84}$ It is straightforward to notice that the equilibrium in the one-period game gives the minmax of $M$ 's payoff.
} 
gies and $R$ 's inability to coercively extract any positive sum from $M$, if $M$ were to deviate and transfer $R$ a sum lower than $\underline{V}_{R}(\underline{c})$, he would optimally invest $q_{M}=q^{*}=0$. Hence, in order for $M$ not to deviate, the following $\mathbf{I C C}(M)$ has to hold:

$$
\frac{\underline{y}-\underline{V}_{R}(\underline{c})}{1-\beta_{M}} \geq \underline{y}+\frac{\beta_{M}}{1-\beta_{M}} U^{s},
$$

and where $M$ sets $q_{M}=q^{*}=0$. We now show that, for every $q_{M} \in\left[0, q_{R}\right], M$ strictly prefers deviating rather than staying in the cooperation phase.

Compare the above-mentioned strategy by $R$ to the one played in Lemma 2, i.e. absent political institutions. In Lemma 2 also, $R$ punishes $M-$ when not receiving an adequate transfer - by reverting to the equilibrium of the finitely repeated game. The two subgames only differ in that $M$ gets a higher deviation payoff when $I_{\tau}=M$. In fact, if $I_{\tau}=M, M$ 's payoff from deviating is given by $\underline{y}$, which is greater than $\underline{y}-f\left(q_{R}\right)$, i.e. the payoff he gets when deviating in period $\tau$ if $I_{\tau}=R$ instead.

Hence, we conclude that $\mathbf{I C C}(M)$ is violated $\forall q_{M} \in\left[q^{*}, q_{R}\right)$ provided $t_{M} \geq \underline{V}_{R}(\underline{c}) .{ }^{85}$

To summarize, in a manorial economy no political institutions arise, i.e. $\widetilde{I}=R$, and the equilibrium pair $\{\widetilde{t}, \widetilde{q}\}$ is given by $\left\{t_{R}, q_{R}\right\}$ as defined in Lemma 2 .

Consider now the case of a Trade economy. If $I_{\tau}=R$, as in the previous case, for $R$ to weakly prefer $I_{\tau}=R$ to $I_{\tau}=M, M$ has to commit to:

$$
t_{M}\left(\bar{c}, \beta_{R}\right) \geq \bar{V}_{R}\left(\bar{c},, \beta_{R}\right) \equiv t_{R}-C\left(q_{R}\right)
$$

where $\bar{V}_{R}\left(\bar{c}, \beta_{R}\right)$ is $R$ 's per-period payoff in a trade economy absent political institutions.

\footnotetext{
${ }^{85}$ Any movement toward efficiency violates $\mathbf{I C C}(M)$. We show this by contradiction. Assume $M$ is weakly better off when playing $q_{M} \in\left[q^{*}, q_{R}\right)$ and transferring $t_{M}=t_{R}-\underline{c} q_{R}$ rather than reneging and induce coercive extraction. Then we should have $q_{R}=q_{M}$ (i.e., from Lemma $2, R$ could have induced this more efficient investment even absent political institutions), a contradiction.
} 
$\bar{V}_{R}\left(\bar{c}, \beta_{R}\right)$ is computed in Lemma 3 along with $\left\{t_{R}, q_{R}\right\}$.

When institutions are granted, $M$ sustains the cost $\underline{c} q_{M}$ of investing in the bureaucracy. $R$ 's two-phase strategy has been previously defined, and the temptation to deviate rests on $M$ when $I_{\tau}=M$. Following any deviation by $M, R$ and $M$ revert to the equilibrium in the one-period stage game forever after.

We first consider $M$ 's payoff when not deviating on the transfer to be made to $R$. In each period $\tau, M$ solves the following problem:

$$
\begin{gathered}
\max _{\{t, q\}} y(q)-\underline{c} q-t \\
t \geq \bar{V}_{R}\left(\bar{c}, \beta_{R}\right),
\end{gathered}
$$

The constraint ensures that $R$ is willing to grant political institutions in each period $\tau$. From the program in (18) it is easily seen that $M$ optimally invests $q_{M}=q^{*}(\underline{c})$.

The grant of political institutions $\left(I_{\tau}=M\right)$ in every period $\tau$ is an equilibrium if $M$ does not find it profitable to deviate, i.e. if:

$$
y\left(q^{*}\right)-\underline{c} q^{*}-\bar{V}_{R}\left(\bar{c}, \beta_{R}\right) \geq\left(1-\beta_{M}\right)\left[y\left(q^{*}\right)-\underline{c} q^{*}\right]+\beta_{M} \underline{u}_{M},
$$

were $(\mathbf{I C C}(M))$ takes into account the possibility for $M$ to set his own preferred level of investment when deviating. Since $R$ cannot induce coercive extraction in stage 4 , it is straightforward to show that, even when deviating, $M$ 's optimal investment is given 
by $q^{*}(\underline{c}){ }^{86}(\mathbf{I C C}(M))$ is written as:

$$
\beta_{M}\left[y\left(q^{*}\right)-\underline{c}^{*}-\underline{u}_{M}\right] \geq \bar{V}_{R}\left(\bar{c}, \beta_{R}\right) .
$$

A sufficiently long-sighted $M$ is needed to make political institutions a subgame perfect equilibrium. Also, all else equal, the more short-sighted $R$ and the higher $\bar{c}$, the lower $\bar{V}_{R}\left(\bar{c}, \beta_{R}\right)$ and, therefore, the more likely political institutions are to arise.

\footnotetext{
${ }^{86}$ The optimal investment is derived by assuming $M$ 's marginal cost of investing in the bureaucracy is $c$ even when deviating on the transfer to $R$. In light of our analysis in the Technical Appendix this may not be true: since $M$ looses appointment rights in future periods, appointed officers may be tempted to keep the higher possible amount of the collected tax proceeds. This may result in a higher wage for officers. We here avoid this possible effect since it does not affect our results in any major way. More specifically, taking this effect into account makes political institutions more likely since it bridles $M$ 's temptation to deviate.
} 


\section{References}

- Acemoglu, Daron, "Politics and Economics in Weak and Strong States", Journal of Monetary Economics, 52 (2005), 1199-1226.

- Acemoglu, Daron, and James A. Robinson, "Why Did the West Extend the Franchise? Democracy, Inequality, and Growth in Historical Perspective", The Quarterly Journal of Economics, 115 (2000), 1167-1199.

- Acemoglu, Daron, and James A. Robinson, "A Theory of Political Transition", The American Economic Review, 91 (2001), 938-963.

- Acemoglu, Daron, and James A. Robinson, Economic Origins of Dictatorship and Democracy, Cambridge University Press, 2006.

- Acemoglu, Daron, Michael Golosov, and Aleh Tsyvinski, "Notes and Comments, Political Economy of Mechanisms", Econometrica, 76 (2008), 619-641.

- Acemoglu, Daron, Davide Ticchi, and Andrea Vindigni, "A Theory of Military Dictatorships", American Economic Journal: Macroeconomics, 2 (2010), 1-42.

- Ballard, Adolphus, The Domesday Boroughs, Clarendon Press, 1904.

- Ballard, Adolphus, British Borough Charters, 1042-1216, Cambridge University Press, 1913.

- Ballard, Adolphus and James Tait, British Borough Charters, 1216-130\%, Cambridge University Press, 1923.

- Bardhan, Pranab, "Decentralization of Governance and Development", The Journal of Economic Perspectives, 16 (2002), 185-205. 
- Bardhan, Pranab and Dilip Mookherjee, "Decentralisation and Accountability in Infrastructure Delivery in Developing Countries", The Economic Journal, 116 (2006), 101-127.

- Barzel, Yoram, and Edgar Kiser, "The Development and Decline of Medieval Voting Institutions: a Comparison of England and France", Economic Inquiry, 35 (1997), 244-260.

- Bates, Robert and Da-Hsiang D. Lien, "A Note on Taxation, Development and Representative Government", Politics 86 Society, 14 (1985), 53-70.

- Besley, Timothy, and Torsten Persson, "The Origins of State Capacity: Property Rights, Taxation and Policy", The American Economic Review, 99 (2009), 12181244.

- Besley, Timothy, and James A. Robinson, Quis Custodet Ipsos Custodes? Civilian Control over the Military, Journal of the European Economic Association, 8 (2010), 655-663.

- Bisson, Thomas M., The Crisis of the Twelfth Century: Power, Lordship, and the Origins of European Government, Princeton University Press. Princeton, NJ, 2008.

- Bloch, Marc, Feudal Society, Vol. 2, Social Classes and Political Organization, Routledge \& Kegan Paul, London, 1964.

- Buchanan, James M., The Limits of Liberty: between Anarchy and Leviathan, University of Chicago Press, 1975.

- Cervellati, Matteo, Piergiuseppe Fortunato, and Uwe Sunde, "Hobbes to Rousseau: Inequality, Institutions and Development", The Economic Journal, 
118 (2008), 1354-1384.

- De Lara, Yadira G., Avner Greif, and Saumitra Jha. "The Administrative Foundations of Self-enforcing Constitutions", The American Economic Review: Papers 65 Proceedings, 98 (2008), 105-109.

- Dessí, Roberta, and Salvatore Piccolo, "Two is a Company, N is a Crowd? Merchant Guilds and Social Capital", CEPR Discussion Paper n. 7374, 2009.

- Dixit, Avinash, "Trade Expansion and Contract Enforcement", Journal of Political Economy, 111 (2003), 1293-1317.

- Djankov, Simeon, Edward Glaeser, Rafael La Porta, Florencio Lopez De Silanes, and Andrei Shleifer, "The New Comparative Economics", Journal of Comparative Economics, 31 (2003), 595-619.

- Egorov, Georgy, Sergei Guriev, and Konstantin Sonin, "Why Resource-poor Dictators Allow Freer Media: A theory and Evidence from Panel Data, American Political Science Review, 103 (2009), 645-668.

- Finer, Samuel E., The History of Government From the Earliest Times, Volume III: Empires, Monarchies, and the Modern State, Oxford, Oxford University Press, 1997.

- Gellner, Ernest, Plough, Sword, and Book: The Structure of Human History, University of Chicago Press, 1992.

- Gennaioli, Nicola, and Hans J. Voth, "State Capacity and Military Conflict", Mimeo Pompeu Fabra University, 2012.

- Giry, Arthur, Histoire de la Ville de Saint-Omer et de Ses Institutions jusqu'au XIVe Siecle, F. Vieweg, 1877. 
- Giry, Arthur, Les Etablissements de Rouen, vol 1 F. Vieweg, 1883.

- Green, Judith A., The Government of England under Henry I, Cambridge University Press, 1986.

- Greif, Avner, "Contract Enforceability and Economic Institutions in Early Trade: The Maghribi Traders'Coalition", The American Economic Review, 83 (1993), $525-548$.

- Greif, Avner, "Commitment, Coercion, and Markets: The Nature and Dynamics of Institutions Supporting Exchange", in Handbook of New Institutional Economics, Ménard, Claude, and Maty M. Shirley, ed. (Springer, 727-786, 2005).

- Greif, Avner, Paul Milgrom and Barry R. Weingast, "Commitment, and Enforcement: The Case of the Merchant Guild", Journal of Political Economy, 102 (1994), 745-776.

- Greif, Avner and Guido Tabellini, "Cultural and Institutional Bifurcation: China and Europe Compared", The American Economic Review: Papers 83 Proceedings, 100 (2010), 135-140.

- Gross, Charles, The Court of Piepowder, The Quarterly Journal of Economics, 20 (1906), 231-249.

- Hodgett, Gerald A.J., A Social and Economic History of Medieval Europe, Taylor \& Francis US, 2006.

- Horowitz, Andrew W., "Time Paths of Land Reform: A Theoretical Model of Reform Dynamics", The American Economic Review, 83(1993), 1003-1010.

- Kadens, Emily, "Order within Law, Variety within Custom: the Character of the Medieval Merchant Law", Chicago Journal of International Law, 5 (2004), 39-65. 
- Konrad, Kai A., Stergios Skaperdas, "The Market for Protection and the Origin of the State", Economic Theory, 50 (2012), 417-443.

- Kiser, Edgar, "Markets and Hierarchies in Early Modern Tax Systems: A Principal-Agent Analysis", Politics $\&$ Society, 22 (1994), 284-315.

- Lane, Frederic C., "Economic Consequences of Organized Violence", The Journal of Economic History, 18 (1958), 401-417.

- Levi, Margaret, "Death and Taxes: Extractive Equality and the Development of Democratic Institutions", in Democracy's Value, Shapiro, Ian, and Casiano Hacker-Cordon, ed. (Cambridge University Press, 1999).

- Levin, Jonathan, "Relational Incentive Contracts", The American Economic Review, 93 (2003), 835-857.

- Lizzeri, Alessandro and Nicola Persico, "Why Did the Elite Extend the Suffrage? Democracy and the Scope of Government, with an Application to Britain's "Age of Reforms"", The Quarterly Journal of Economics, 119 (2004), 707-765.

- Lopez, Robert S., The Commercial Revolution of the Middle Ages, 950-1350, Prentice Hall, 1971.

- Machiavelli, Niccoló, Selected Political Writings: The Prince, Selections from the Discourses, Letter to Vettori, Hackett Publishing, 1994.

- Maitland, Frederic W., Domesday Book and Beyond: Three Essays in the Early History of England, Cambridge University Press, 1897.

- Malcomson, James M., "Relational Incentive Contracts", in The Handbook of Organizational Economics, Gibbons, Robert, and John Roberts, ed. (Princeton University Press, 2013). 
- Mayshar, Joram, Omer Moav, and Zvika Neeman, "Transparency, Appropriability and the Early State", CEPR DP, (8548), 2011.

- McGuire, Martin C., and Mancur L. Olson, "The Economics of Autocracy and Majority Rule: The Invisible Hand and the Use of Force", Journal of Economic Literature, 34 (1996), 72-96.

- Merewether, Henry A., The History of the Boroughs and Municipal Corporations of the United Kingdom, from the Earliest to the Present Time: with an Examination of Records, Charters, and other Documents, Vol. 1, Stevens and sons, London, 1835.

- Moselle, Boaz and Benjamin Polak, "A Model of a Predatory State", Journal of Law, Economics and Organization, 17 (2001), 1-33.

- Myerson, Roger B., "The Autocrat's Credibility Problem and Foundations of the Constitutional State", American Political Science Review, 102 (2008), 125-39.

- North, Douglass C., "Institutions and Credible Commitment", available at SSRN: http://ssrn.com/abstract=6042, 1999.

- North, Douglass C. and Robert P. Thomas, The Rise of the Western World: A New Economic History, Cambridge University Press, 1973.

- North, Douglass C., John J. Wallis and Barry W. Weingast, Violence and Social Orders: A Conceptual Framework for Interpreting Recorded Human History, Cambridge University press, 2009.

- North, Douglass C. and Barry R. Weingast, "Constitutions and Commitment: The Evolution of Institutions Governing Public Choice in Seventeenth-Century England", The Journal of Economic History, 49 (1989), 803-832. 
- Olson, Mancur L., Dictatorship, Democracy and Development, American Political Science Review, 87 (1993), 567-576.

- Pirenne, Henri, "Medieval Cities. Their Origins and the Revival of Trade", Princeton University Press, Princeton, 1925.

- Reynolds, Susan, An Introduction to the History of English Medieval Towns, Clarendon Press, Oxford, 1977.

- Reynolds, Susan, "Government and Community", in The New Cambridge Medieval History, c. 1024 - c. 1198, Vol. IV, Luscombe, David, and Jonathan Riley-Smith, ed. (Cambridge University Press, 2004).

- Ryerson, Kathryn L., "Commerce and Communication", in The New Cambridge Medieval History, c. 1198 - c. 1300, Vol. V, Abulafia, david, ed. (Cambridge University Press, 1999).

- Sachs, Stephen E., "From St. Ives to Cyberspace: The modern Distortion of the Medieval Law Merchant", American University International Law Review, 21 (2006), 686-812.

- Sheppard, Francis, London: A History, Oxford University Press, 1998.

- Slivinski, Al, and Nathan Sussman, "Tax Administration and Compliance: Evidence from Medieval Paris", Mimeo, University of Western Ontario, CA, 2012.

- Sng, Tuan-Hwee, and Chiaki Moriguchi, "Taxation and Public Goods Provision in China and Japan before 1850", PRIMCED Discussion Paper Series 35, Institute of Economic Research, Hitotsubashi University, 2013.

- Stasavage, David, States of Credit: Size, Power, and the Development of European Polities, Princeton, NJ: Princeton University Press, 2011. 
- Stephenson, Carl, Borough and Town: a Study of Urban Origins in England, Mediaeval Academy of America, 1933.

- Stubbs, William, Select Charters and Other Illustrations of English Constitutional History from the Earliest Times to the Reign of Edward the First, Clarendon Press, 1905.

- Tait, James, The Medieval English Borough; Studies on its Origins and Constitutional History, Manchester University Press, 1936.

- Thierry, Augustin, Lettres sur l'Histoire de France, Vol. 1, Garnier, 1867.

- Tilly, Charles, "War Making and State Making as Organized Crime", in Bringing the State Back In, Evans, Peter, Dietrich Rueschemeyer, and Theda Skocpol, ed. (Cambridge, Cambridge University Press, 1985).

- Usher, Abbott P., An Introduction to the Industrial History of England, Boston, New York [etc.] Houghton Mifflin Company, 1920.

- Volckart, Oliver, and Antje Mangels, "Are the Roots of the Modern Lex Mercatoria Really Medieval?", Southern Economic Journal, 65 (1999), 427-450.

- White, Lynn T., Medieval Technology and Social Change, Oxford University Press, Oxford, 1964.

- Willard, James F., Parliamentary Taxes on Personal Property, 1290 to 1334: a Study in Mediaeval English Financial Administration, Mediaeval Academy of America, Cambridge, 1934. 